\title{
Agricultural Labor and National Labor Legislation
}

\author{
Austin P. Morris, S.J.*
}

"These people now perhaps are deluded with the thought that you people down here in Washington are backing them up and are going to help them through."'I

A GRICULTURAI WORKERS IN 1939, to whom the above quotation refers, were unlikely to have been quite so deluded. Only four years before, they had been excluded from legislation protecting the worker's right to organize and bargaim collectively through freely chosen representatives. ${ }^{2}$ Excluded also from the Social Security and the Fair Labor Standards Act, ${ }^{3}$ agricultural labor had learned, by 1939, to expect little from Congress. However sensitive that body had been to the needs of industrial labor, it had been totally unresponsive to similar, if not more critical, ${ }^{4}$ needs of the farm work force.

In excluding agricultural labor from the National Labor Relations Act, Congress overlooked its own national policy, which was to eliminate "the causes of certain substantial obstructions to the free flow of cominerce." These causes were found to be:

[1] the demal by employers of the right of employees to organize and the refusal by employers to accept the procedure of collective bargaining [which] lead to strikes ... obstructing commerce ... [2] the inequality of bargaiming power between employees ... and employers ... [which] burdens . . . commerce ... by depressing wage rates and the purchasing power of wage earners in industry and by preventing the stabilization of competitive wage rates and working conditions within and between industries. ${ }^{6}$

* B.A., 1948, LL.B., 1950, University of California, Berkeley; M.S.T., 1963, University of Santa Clara; LLM., 1966, University of California, Berkeley. Assistant Professor of Law, University of San Francisco.

1 Hearings on S. 1000, S. 1264, S. 1392, S. 1550, S. 1580, and S. 2123 Before the Senate Committee on Education and Labor, 76th Cong., 1st Sess. 3591 (1939) (testimony of T. A. Buhl).

2 National Labor Relations Act (Wagner Act) \& 2(3), 49 Stat. 450 (1935), 29 U.S.C. \$ 152(3) (1964): "When used in this Act .... (3) the term 'enployee' shall include any employee ... but shall not include any individual employed as an agricultural laborer."

3 Social Security Act $\$ 210$ (b) (1), 49 Stat. 625 (1935) (now 42 U.S.C. $\$ \S 409$ (h) (2), 410(a) (1), 413(a)(2) (iv) (1964)); Fair Labor Standards Act § 13(a)(6), 52 Stat. 1067 (1938), 29 U.S.C. \& $213(\mathrm{a})(6)$ (1964).

4 "[T]here is not a single solitary reason why agricultural workers should not be included under the provisions of this bill. The sane reasons urged for ... [industry] are equally applicable in the case of agricultural workers, in fact nore so as their phight calls for imnediate and prompt action." H.R. REP. No. 969, 74th Cong., 1st Sess. 27 (1935).

5 National Labor Relations Act \& 1, 49 Stat. 449 (1935), 29 U.S.C. § 151 (1964).

6 Ibid. (For a discussion of strikes in agriculture during the thirties, see note 116 infra.) 
In light of these findings, Congress chose, as the means of eliminating the causes of these burdens on commerce, to protect the worker's riglit to organize and bargain collectively through lis elected representatives. Considering that agricultural labor relations are and have been characterized by the above deficiencies to a marked degree, ${ }^{8}$ one might suppose that the logical implications of Congress's declared national policy would have impelled it to include agriculture within the scope of the National Labor Relations Act.

It is important to understand the influences which have operated over the past thirty years to continue the exclusion of agricultural labor from national labor legislation. This is particularly true at the present time when there are signs that the attitude of Congress, and of the public at large, is beginning to change in this area. ${ }^{0}$ There is still, however, considerable reluctance in Washington to extend the protections of the

7 "It is lereby declared to be the policy of the United States to eliminate the causes [which obstruct commerce] ... by encouraging the practice ... of collective bargaining and by protecting ... full freedom of association, self-organization, and designation of representatives of their own choosing." Ibid.

${ }^{8}$ See Jamieson, Labor Unionism in American Agriculture, in U.S. BUREAU OF LABOR Statistics, DEP'T OF LABOR, BULI. No. 836 (1945), which records the abysmal failure of farm workers to establish any permanent umion organization. That recognition and contract negotiation by Schenley Industries, Inc. with the National Farm Workers Association could only be regarded as "historic" in 1966 is an indication of the primitive nature of labor relations in agriculture. San Francisco Examimer, June 21, 1966, p. 2, col. 1 (final edition). The depressed condition of wages, and hence purclasing power, of agricultural workers is well known. In 1960 the average cash wage earnings of year-round farm workers (excluding perquisites), employed an average of 321 days, was $\$ 2,255-\$ 7.05$ a day. Regular workers, employed an average of 191 days, earned $\$ 1,113$, or $\$ 5.85$ a day. In 1962 the year-round worker averaged $\$ 2,477$ for 315 days of employment- $\$ 7.85$ a day. Regular employees earned $\$ 1,200$ for 191 days $\$ \$ 6.30$ a day. Data for 1960 is from U.S. DEP'T OF AGRTcutruRE, AGRICULTURE INFORMATION BULI. No. 266, at 4, in conjunction with table 7, at 33 (1962); for 1962, Economac Research SERVICE, U.S. Dep'T of Agriculdure No. 141, at 6, table 4 (Oct. 1963). The average hourly wage for the United States, in 1965, was $\$ 1.16$. See U.S. DEP'T OF LABOR, YeAR OF Transityon app. E (1966).

${ }^{9}$ In 1963 Congress refused to extend the Agricultural Workers Importation Act (Mexican), 65 Stat. 119 (1951) [hereinafter referred to as the Bracero law], thus allowing it to expire on December 31, 1964. Enacted in 1951, the law had permitted importation of Mexican nationals to work on America's farms. The law required, as protection for domestic workers, certification by the Secretary of Labor that "able, willing, and qualified" local labor was not available. 65 Stat. 120 . Wages paid Braceros were not to "adversely affect" domestic wages of farm labor, and growers were supposed to use "reasonable efforts" to attract domestic workers before seeking Braceros. Ibid. It was charged that the law was not administered in accordance with its spirit, that Bracero-users never seriously tried to attract domestic labor, and that wages were kept down, and even lowered. See GaLARzA, MERcrhanTs of LABOR (1964), for a documented criticism of the program. That little effort was made, either by administrative insistence or grower cooperation, to recruit local workers is evidenced by the fact that as the number of entrants was cut down toward the end of the program (from a high of 459,850 in 1956 to about 200,000 in 1964, and only 20,000 in 1965), their places were taken by domestic workers. If domestic workers could be recruited in 1965, as they were, then clearly they could lave been recruited in 1956 . 
NLRA to farm workers. Not only is there a certain inertia against overturning establisled policy, but it is also possible that the long-standing arguments supporting exclusion have hardened into assumptions too difficult to break down. Similar assumptions were evident during the years of the Bracero program..$^{10}$ The argument put forward to justify the demand for Mexican nationals was built around a claimed slortage of domestic farm labor. It was constantly charged that there were not enough Americans willing and able to do "stoop" labor. The corollary of this position predicted as the inevitable consequence of cutting off or denying access to the foreigu labor supply all manner of disaster to that sector of agriculture dependent upon a large seasonal work force, chiefly fruits and vegetables. ${ }^{11}$

Impressed by these arguments and alarmed by the frightful prospects, Congress continued to renew the Bracero program, ignoring the argument advanced by its opponents that there would be a sufficiency of domestic labor for liarvest labor if wages and working conditions were only improved. ${ }^{12}$ While the Bracero law was operating, this latter theory could lrardly be adequately tested.

Beginning in 1961, the administration of the Bracero law began to be tightened. The numbers of Mexican nationals certified for agricultural work decreased from over 400,000 in 1956 to about 200,000 in $1964 . .^{13}$ In 1965, after the Bracero program terminated, only 20,300 Mexican nationals were permitted to enter the country for work in the fields. ${ }^{14}$

10 Importation of supplementary agricultural labor from Mexico began during World War II. In 1942 some 1,500 Mexicans were used in California over the objection of American and Mexican-American labor organizations which insisted that no need existed. CALIFORNIA Senate fact Finding Comm. on Labor and Wetfare, California's Farm Labor Problems pt. I, at 72 (1961). The earher laws were of little significance because of the growing importance of illegal entrants-Wetbacks-who were attracted across the border by the spreading news of available jobs up north. Growers continued to rely on the Wetbacks until 1954 when, as a result of increased appropriations, the Immigration Service was able to stem the flow. The preference for Wetbacks, if available, is understandable; no government procedures need be complied with and there are no transportation costs involved.

11 This argument reached a' crescendo after the Bracero law terminated in 1964. Senator Ellender, for example, declared on the Senate floor: "[F]armers protested that they would be unable ... to obtain adequate labor to harvest their crops and would suffer great losses thereby, that it would be necessary to reduce plantings because of the uncertainty that harvest labor would be available." 111 CoNg. Rec. 3015 (daily ed. Feb. 18, 1965).

12 FULIER, LABOR RELATIONS IN AGRICULTURe 23-26 (1955), summarizes the arguments for and against the supplemental foreigu labor program.

13 DeP'T OF LABOR, YEAR of TRANSITION 11 (1966).

14 Id. at 5 . The authority for this importation was derived from the Immigration and Nationality Act, 66 Stat. 163 (1952), as amended, 8 U.S.C. $\$ \S 1101-503$ (1964), which was passed over the President's veto in 1952. Under this law aliens can be brought into the Umited States for employment "if unemployed persons capable of performing such service or labor cannot be found in this country." 66 Stat. 168 (1952), 8 U.S.C. $\$ 1101$ (a) (15) (H) (ii) (1964). Petitioners for such labor must meet conditions approved or prescribed by the 
The horrendous consequences that were predicted as absolute certainties if the supplemental foreign labor supply were cut off failed utterly to materialize. In fact, agriculture had one of its best years, with crop values up even in crops affected by labor shortages. ${ }^{15}$

The repeated and carefully nurtured argument that Americans would not do stoop labor was proved to be a myth in 1965-the very first year of a stubbornly resisted transition to domestic labor. The real basis for the alleged difficulty in obtaining local labor was exposed. As the Labor Department put it:

The attention attracted by Congress' termination of P.L. 78 and the establishment by the Secretary of Labor of firmer policies for administering P.L. 414 has concealed this central fact: the reduced use of foreign labor was brought about primarily by the decision of American growers to improve wages and working conditions and by the operation of employment and technological forces. ${ }^{10}$

Attorney General, whose duty it is to consult with other affected governmental agencies. In this case the criteria which had to be met were formulated in late 1964 by the Secretary of Labor after several hearings. 20 C.F.R. $\$ 602.10$ (1966). In essence they established the conditions which were supposed to have been observed under the Bracero law. Before any petitioning farmer, or farm association, would be cleared for obtaining forcign workers he had to present proof of compliance with regulations recuiring "reasonable efforts . . . to obtain domestic workers." 20 C.F.R. $\$ 602.10$ (a)(1) (1966). Furthermore, in order to insure against adverse effect on local wages and working conditions, certification for foreign workers would be denied unless petitioners offered employment to domestics according to an established schedule of wages (varying from $\$ 1.15$ an hour in Florida to $\$ 1.40$ in California). 20 C.F.R. \& 602.10(2)-(5) (1966). Unless specifically exempted, each petitioner was to offer domestic workers "all the terns and conditions of employment ... offered to Mexican workers under [the old Bracero law]," 20 C.F.R. $\$ 620.10$ (2)(c)(1)(ii) (1966), including a written contract embodying those conditions. If the Bracero law had been administered according to these criteria, which were designed to eliminate the possibility of adverse effect on the domestic work force, the importation of Mexican nationals would have always been a minor factor in agricultural labor as it was in 1965.

15 "[T] $[$ he total of even the claimed losses due to labor shortage in 1965 is estimated at less than $1 / 2$ of 1 per cent of the value this year of crops which foreign labor worked on in 1964." DEp'T of LABOR, YEAR of Transition 15 (1966). Crop values were up, over 1964 figures, in these crops: fresh asparagus: $\$ 1,441,000$; processing asparagus: $\$ 2,444,000$; fresh tomatoes: $\$ 10,816,000$; processing tomatoes: $\$ 19,558,000$; cucumbers for pickles: $\$ 4,380,000$; and lettuce: $\$ 17,872,000$. Id. at 18 . These crops (and strawberries) suffered from labor shortages. It is possible that growers contributed to the problem by their reluctant acceptance that the Bracero law was really over and done with and that the Immigration Act was not going to provide a substitute for the old program. See id. at 15-18.

16 Id. at 11. The Departnent of Labor is too modest in giving growers so much crcdit for this decision, an opimion not shared by everyone. The Fort Lauderdale (Fla.) News, Jan. 31, 1965, for example, suggested a different source: "If the Great Society architects apply the sanie kind of reasoning to other problems as they are applying to the problem of finding an adequate source of labor for the Nation's fruit and vegetable producers, [the country will be in one] 'neell of a liess.' . . . Some tine ago . . . the big thinkers of the U.S. Department of Labor came to the conclusion that with millions of Americans out of work it was silly to go on permitting agricultural interests to import their labor needs from foreign countries." Quoted in 111 Conc. REc. 3048 (daily ed. Feb. 18, 1965). 
The hard fact emerging from this experience is that Congress enacted and continued the Bracero program under the influence of an essentially false argument: that domestic workers could not be found to do agricultural labor. The argument was made with persistence, imagination, and extreme exaggeration. ${ }^{17}$ Unquestionably, in the minds of many it had become an unassailable assumption, a solid basis for keeping foreign laborers accessible for agriculture. The cost to the American farm worker, forced to compete with what in fact was a surplus work force of men more than willing and able to work for the low wages offered, has been immense. ${ }^{18}$

Congress's reasoning in providing agriculture with foreign labor was similar to that behind its exclusion of agricultural labor from legislation protecting the worker's right to self-organization. This reasoning has led Congress to overlook, or put aside, all the arguments favoring extension of national labor legislation to cover farm workers, including the clear implications of national policy. ${ }^{19}$ A question deserving of serious consideration, especially in light of the exploded theory so long asserted as justification for the Bracero program, is whether this exception to national labor policy may not have also been founded on just as false, exaggerated, and baseless a position. To answer the question adequately, the legislative history of the exclusion must be analyzed.

Some are of the opinion that agricultural political power has been the sole cause of congressional inaction respecting agricultural labor. ${ }^{20}$

17 Senator George Murphy (R-Calif.), arguing that the immigration law should be administered in such a way as to provide easy access to the foreign labor pool, declared in his first speech on the Senate floor: "It is our desire that domestic labor fill these jobs. But the facts must be faced. Domestic labor has not, will not, cannot, or does not desire, in many cases, to fill these jobs. We are now at the crossroads as to whether we lose 30 per cent of the largest industry in California. This industry contributes $\$ 15.5$ billion to our economy. Whether we lose 30 per cent of that industry this year, and more next year, depends on whether the Secretary of Labor has further meetings and relaxes his system a httle." 111 Cong. REc. 3024 (daily ed. Feb. 18, 1965). (Emphasis added.) Without relaxing the system, 20,300 Mexican nationals were allowed to enter California in 1965, considerably less than demanded by the growers. See text accompanying note 14 supra. Admittedly they contributed to the farm economy, but it would be absolutely ridiculous to suggest that this small number kept the industry from suffering the $\$ 4.65$ billion loss promised by the Senator if they had been kept out.

18 In California, where farm wages are better than in other parts of the country (except Hawaii where farm workers have been organized for years), agricultural workers average about $\$ 2,000$ a year. The poverty level for annual income is estimated at $\$ 3,000$ in the United States. Nattonat, Advisory Comm. on Farm Labor, The Grape Strike 3 (1966).

10 See text accompanying notes 5-7 supra. For the history behind the development of this policy, see Rubinow, Section $7(a)$ : Its History, Interpretation and Administration, in Division of Review, Nationat Recovery Adm'N., Work Materials No. 45 E (1936).

20 "[P] excluding domestic farm workers from nearly all labor and welfare legislation." Comment, Agricultural Labor Relations-The Other Farm Problem, 14 StaN. L. Rev. 120, 127 (1961). 
Others assert complex probabilities: possible lack of legislative power due to viewing agriculture as an intrastate activity, complicated legal problems, and administrative difficulties. ${ }^{21}$ These conflicting opinions require some evaluation.

This article will explore the legislative history behind the exclusion of agricultural labor from national labor legislation, from just prior to passage of the Wagner $\mathrm{Act}^{22}$ to date. Reams have been written about the disadvantaged status of the agricultural laborer. ${ }^{23}$ The wretchedness of his economic position, his almost total lack of bargaining power vis-a-vis his highly organized farmer-employers, and the woeful insufficiency of his political strength are largely a result of the failure to effect self-organization. This lack of self-organization can be traced in significant degree to the failure to provide any legal protection of the farm workers' right to organize. ${ }^{24}$

To evaluate the history of the agricultural exclusion it is necessary first to develop agriculture's position against labor legislation for farm workers, and then to answer it. To consider the economic conditions of agricultural labor, to investigate factors other than the lack of legal protection that have prevented self-organization, or even to argue from justice and the need for equality under the law, while meritorious, does not meet the arguments of agriculture against labor legislation. The scope of this article will therefore be limited to tracing the development of the arguments which lave been consistently proposed in favor of continuing the present exclusion, and to describing the events which have demonstrated, over and over again, the irrelevant nature of agriculture's thinking in relation to orgamized labor.

21 "[It was] not so much ... political power . . . as it was the ... reluctance of Congress to impose statutory regulation on agriculture ... traditionally considered an intrastate activity. . . . [Congress was also probably deterred by] the very complex legal questions involved .... . [and] the extremely complex administrative problems which would be involved." Comment, Agricultural Labor Relations-The Other Farm Problem: A Rebuttal, 15 STAN. L. Rev. 616, 618-19 (1963).

22 See note 2 supra.

23 See S. Rep. No. 155, 89th Cong., 1st Sess. (1965); S. ReP. No. 167, 88tl Cong., 1st Sess. (1963); Hearings on S. 1085 Before a Subcommittee of the Senate Conmittee on Labor and Public Welfare, 86th Cong., 1st Sess. (1959); Prestoent's Coman's on Mioratory Labor, Migratory Labor in American Agrictuture (1951). A report of the most thorough congressional investigation into farm labor is contained in S. REP. No. 398, 78th Cong., 2d Sess. (1944), and S. Rep. No. 1150, 77th Cong., 2d Sess. (1942) (final reports of the Senate Committee on Education and Labor-the so-called "La Follette Committee"-investigating violations of free speech and rights of labor).

24 See Mornd, The Organizabictry of Farm Laeor in the UnTted States (1952), which details the principal difficulties inpeding organization of farm workers. 
AGRICUITURAI IABOR AND THE NATIONAL INDUSTRIAL RECOVERY ACT ${ }^{25}$

An analysis of agricultural workers and the NLRA should begin with the brief period of the New Deal's recovery program. It was during this era that the precedent of exclusion was firmly established. ${ }^{26}$ In attempting to restore the nation's economy to operating efficiency, two broad programs for recovery were developed: one for agriculture, ${ }^{27}$ the other for industry. ${ }^{28}$ Convinced that neither plan could possibly succeed without substantial voluntary participation, ${ }^{29}$ Congress tried to adapt each program to the separate needs of those participants whose support was believed to be more or less essential.

This spirit of accommodation, plainly manifest while the recovery bills were being drafted, ${ }^{30}$ and especially while they were being administered, ${ }^{31}$ accounts for the marked contrast between the agricultural and industrial programs respecting labor. Although the agricultural bill was devoid of any provisions for labor, the industrial bill, both as initially drafted and as amended, ${ }^{32}$ was definitely responsive to the demands and influence of orgamized labor.

The reasons for this contrast are not difficult to isolate. In the first

2548 Stat. 195 (1933). The act was declared unconstitutional in Schechter Poultry Corp. v. United States, 295 U.S. 495 (1935).

26 Ross, Agricultural Labor and Social Legislation 119 (1941) (unpublished thesis in University of California, Berkeley, Library).

27 The Agricultural Adjustment Act, 48 Stat. 31 (1933) (declared unconstitutional in United States v. Butler, 297 U.S. 1 (1935)).

28 The National Industrial Recovery Act, 48 Stat. 193 (1933).

20 That the emphasis would be on voluntary participation was made abundantly clear during hearings on the industrial recovery program. The principal administration witnesses, Senator Robert Wagner and Mr. Donald Richberg, both stressed this, the latter declaring, "[I]f there is any effectiveness in this type of legislation, it is to come primarily from the voluntary action of industry itself. Unless ... [industry will] cone voluntarily forward and attempt to enforce these agreements, the legislation will be a failure." Hearings Before the Senate Finance Committee on S. 1712 and H.R. 5755, 73d Cong., 1st Sess. 33-34 (1933). (Senator Wagner's statement may be found id. at 1.)

30 For example, Donald Richberg, who had represented labor in the Railroad industry, is believed to have been the drafter of the industrial bill's initial labor provisions. See Edelman, New Deal Sensitivity to Labor Interests, in LABOR AND THE NEW DEAL 165-66 (Derber \& Young ed. 1961).

31 See text accompanying notes 45-53 infra.

32 William Green, President of the American Federation of Labor (AFL), suggested, during the hearings that the bill be amended to protect employees against "interference, restraint, or coercion of employers . . . in [choosing representatives, self-organization and] concerted activities for the purpose of collective bargaining or other nutual aid and protection." Hearings Before the House Committee on Ways and Means on H.R. 5664, 73d Cong., 1st Sess. 117-32 (1933). This suggestion was incorporated into the final act. The National Industrial Recovery Act \& 7(a), 48 Stat. 198-99 (1933). 
place, agricultural interests were absolutely opposed, as they generally are today, to the whole concept of unionism and collective bargaining. ${ }^{33}$ This attitude was shared by the Department of Agriculture, which was responsible for devising and administering the Agricultural Adjustment Act. The consistent policy of the act's administrators was reflected in its belief "that the interests of agricultural workers would be amply safeguarded as a consequence of the benefits to be enjoyed [under the agricultural act] by the farmers who employed them." ${ }^{.34}$

Second, the extent of unionization among agricultural workers was negligible. The organization that did exist was weak, ineffective, and without contact with or representation by organized labor. ${ }^{35}$ Therefore, whether farm workers supported or opposed the agricultural program was a matter of no real concern to its sponsors in Washington. Indeed, farm workers' attitudes were probably not even considered; certainly no one, including the Department of Labor, suggested that the workers should be consulted. Given this hostility of agricultural interests to unionism, the general indifference to the problems of agricultural labor, and the government's policy of placating dominant political and economic interests, it was a foregone conclusion that farm workers would receive no special consideration from the Administration.

Despite the Administration's lack of concern for the agricultural worker, the labor provisions of the NIRA ${ }^{36}$ are addressed to workers

${ }^{33}$ Woodbury, Limits of Coverage of Labor in Industries Closely Allied to Agriculture under Codes of Fair Competition under NIRA, in Drv. OF REviEw, NATIONAI RECovery ADMr'N., WORK MATERIALS No. 45A (1936), writing of agriculture's opposition to NIRA labor codes, stated: "Farmers as a class are opposed to any form of labor organization. Attempts of the I.W.W. in the past to organize migratory harvest hands have helped to give farmers a distaste for unionization of farm labor, a sentiment which deepened into hostility because of the tactics of the I.W.W. group in pulling strikes at critical times during the harvest season." Id. at 4.

34 Id. at 3.

35 What little unionization that had developed in the late twenties had all but disappeared during the first three years of the depression. The few strikes of these years seem to have been little nore than spontanęous protests against wage cuts. Jamieson, supra note 8, at 16. Although organized labor made some mild attempts to organize farm workers during the early part of the century, the effort had died out by the thirties. It did not revive until after 1935. See id. at 55-58.

${ }^{36}$ Section 7(a): "Every code of fair competition ... shall contain the following conditions: 1) That employees shall have the riglit to organize and bargain collectively through representatives of their own choosing, and slall be free from the interference, restraint, or coercion of employers of labor, or their agents, in the designation of such representatives or in self-organization or in other concerted activities for the purpose of collective bargaining or other mutual aid or protection; 2) that no employee and no one seeking employment shall be required to join any company union or to refrain from joining, organizing, or assisting a labor organization of his own choosing ...." 48 Stat, 198-99. See Rubinow, supra note 19, at 7-9, which documents the historical support within the United States for the principle of collective bargaining and union recognition. 
generally. This is clear when one examines the enthusiastic statements promoting this legislation: "The workers of this country have rights under this law which cannot be taken away from them, and nobody will be permitted to whittle them away, but, on the other hand, no aggression is now necessary to attain those rights. ${ }^{137}$ Although the NIRA was deservedly acclaimed by organized labor, ${ }^{38}$ it turned out that agricultural workers had no rights under the law from its inception. ${ }^{39}$

The responsibility for this exclusion has been attributed to Congress, ${ }^{40}$ but a strong argument can be made that it was administrative policy that precluded farm workers from coverage under the NIRA. The act was certainly broad enough in principle and language to include them. ${ }^{41}$ For example, an interdepartmental report on working conditions in the Florida citrus industry declared:

87 Radio message of President Roosevelt, July 24, 1933, quoted in Nattonal RecoverY AdM'N., HANDBOOK FOR SPEARERS, 5-6 (1933).

38 "For the first time in the history of the nation there has been written in a statute passed by the Congress ... a section according workers a legal right to organize and to be protected in the exercise of that right." TAFT, Organized LABOR IN AMIERICAN HISTORY 420 (1964). Passage of the NIRA marked the beginning of the "most extensive organization drive in the history of the American labor movement" as 1933 saw union membership increase by some 800,000 , "greatly, if not entirely, influenced by the protection of the right to organize given in the NIRA." Id. at 419-20.

39 The organizing movement touched off by the NIRA reached even farm workers as dramatic increases in their strike activity were seen in 1933. Confused by the act's broad provisions, many farm workers submitted codes of fair competition to the National Recovery Administration for approval. See Jamieson, supra note 8, at 17-18.

${ }^{40}$ Woodbury, supra note 33, at 3: "[T] not intend that codes of fair competition under the NIRA be set up for farmers or persons engaged in agricultural production." The NIRA authorized industries, trade associations, and subdivisions thereof to set up codes relating to prices, marketing, wages, hours, and so forth. Section 7(a), the concession-to-labor section, required each code to include its provisions. Section 3(d) granted the President, or his delegate, the authority to prescribe such codes where none had been submitted or approved. Section 7 (c) authorized the President to prescribe limited codes relating to hours, wages, and conditions of employment. Senator Wagner, while insisting that the emphasis would be on voluntary participation in setting up the codes, went on to explain the authorization to impose codes where none were submitted or approved. Asked if "all industry must come under some one of these," he answered: "Oh, yes." Senator Couzens then asked: "Agriculture?" Wagner answered: "No." Hearings on H.R. 5644, supra note 32 , at 4 .

41 In spite of the brief but rather definite exchange between Senator Couzens and Senator Wagner, note 40 supra, there is a formidable body of opinion holding that the NIRA did, in fact, cover agricultural labor. No less than the legal division of the Agricultural Adjustment Administration believed that the recovery act authorized a code for farm workers. The Bureau of Agricultural Economics actually drafted a code applicable to them, while recommending that none be adopted. Finally the legal division of the NRA objected to a code clause (submitted by the seed industry) which defined "employee" as any person "except . . . persons exempted under the Act." They argued that agricultural labor was not specifically exempted under the act. Woodbury, supra note 33 , at 3, 21-23 cites these opinions. 
On the initial premises of this Administration that no class is to be ignored, that suffering and exploitation is a signal for directed effort on the part of the Government to alleviate the evils, that the benefits conferred by Government action are not to be bestowed at the top with the hope that they will seep through but are to be carried down by Government direction to all classes, Government intervention .... is called for. ... .

The legislative history of that Act [NIRA] contains some indications that farm labor was not intended to be brought within its labor provisions, though it is not conclusive on the point and a strong argument to the contrary may be made from the terms of the Act itself. ${ }^{42}$

However strongly that argument might be made, no one ever attempted it, including the National Recovery Administration (NRA) which accepted, in practice at least, the Agricultural Adjustment Administration's (AAA) position that agriculture was not required to submit codes of fair competition. Whether Congress intended to exclude agricultural labor from the benefits of the NIRA must be regarded as unsettled. Farm workers would have been excluded from the benefits of the NIRA in any event, given the administrative policies then in existence. ${ }^{43}$

The principal objective of the Agricultural Adjustment Act, which was designed to restore a balanced economy for farmers, was the raising of agriculture's purchasing power through restoring price levels to prewar figures. The means chosen to accomplish this plan was production control. The Secretary of Agriculture was authorized to do a number of things to reduce acreage, cut down on the market supply, and thereby bring the price up to the desired level. ${ }^{44}$ Cost reduction was only a corollary objective.

42 The report of the interdepartmental committee has been reprinted in Woodbury, supra note 33, at 35-38. The committee, apparently without dissent or minority report, added: "A code of fair competition under the NIRA might be imposed [under section 3 (d)] on the citrus industry and its labor provision extended to pickers [obviously agricultural workers] and packing house employees." Id. at 37. The committee, however, impressed by the chaotic work conditions, particularly the irregularity of employment, thought this would not be the adequate solution. Codes were not imposed at any time on any industry.

43 Section 3(a) of NIRA required, as a condition precedent to code approval, that the sponsoring body be "truly representative" of the industry seeking codification. 48 Stat. 193-98 (1933). Since no farm group submitted codes, farm workers would not be covered by $\S 7$ (a) unless the government imposed codes-which was not done. Woodbury, supra note 33, at 2-3. The incentive spurring industry to formulate codes-freedom from the restrictions of antitrust law-did not operate with any force on agriculture. The latter industry obtained the same essential benefits without submitting codes by entering the marketing agreements and crop support programs of the AAA.

44 Beard \& SMctr, THe Future Comes 75 (1933). "The program affirms the determination of the Administration to organize agriculture from the soil to the market, which is a first essential step toward gearing agricultural productivity to effective consumptive capacity within the nation." $I d$. at 90 . 
The NRA, on the other hand, while hoping to keep prices level, encouraged shorter hours and increased wages with the perhaps naive belief that rising costs would be met by expanding sales. ${ }^{45}$ As a matter of fact, prices rose at a faster rate for industrial products than farm products, causing considerable negative reaction from rural communities. ${ }^{46}$ Recalling the congressional policy of eliciting voluntary cooperation with the recovery plans, and recognizing that serious hostility could imperil this policy, it is understandable that the Administration would attempt to appease agricultural interests.

This conciliatory approach was amply demonstrated in settling conflicts between the AAA and NRA over the interpretation of the meaning of agricultural labor. Having accepted the position that agricultural workers need not be covered by codes, the NRA found itself in an immediate dispute with the AAA over a workable defintion of this class of workers. The Florida citrus industry claimed that their work force was not subject to the jurisdiction of the NRA because it was "agricultural labor." A definition was drawn up, allegedly by Dr. Leo Wolman, Chairman of the Labor Advisory Board:

Agricultural workers are all those employed by farmers on the farm when they are engaged in growing and preparing for sale the products of the soil and/or livestock; also, all labor used in growing and preparing perishable agricultural commodities for market in original perishable fresh form. When workers are employed in processing farm products or preparing them for market, beyond the stage customarily performed within the area of production, such workers [are] not to be deemed agricultural workers. ${ }^{47}$

The ambiguity of the phrase "within the area of production" does not seem to have been noticed until the Florida citrus industry interpreted it as excluding their packing house workers from any code negotia-

45 "I am fully aware that wage increases will eventually raise costs, but I ask that managements give first consideration to the improvement of operating figures by greatly increased sales to be expected from the rising purchasing power of the public. ... The aim of this whole effort is to restore our rich domestic market by raising its vast consuming capacity." Natronat Recovery ADMr's op. cit. supra note 37, at 3. And again: "The idea is simply for employers to hire more men to do the existing work by reducing the workhours of each man's week and at the same time paying a living wage for the shorter week." Id. at 1. Both comments are those of the President on signing the NIRA.

46 "The NRA had increased the cost of the things the farmers purchase at the very time [referring to November 1933] that their own products had gone down greatly in price. There was great indignation in many commumities. . . W WaILACE, NeW FroNTIERS 56 (1934), quoted in LYoN, The NatronaI RECOVERy ADMINISTRATION, AN ANALYSIS AND ApPraISAL 713 (1935).

47 Woodbury, supra note 33, at 17. The definition was issued August 19, 1933, two months after the NIRA had become law. Dr. Wolnuan was an economist and statistician whose public service had dated from 1914 when he had been employed by the Commission on Industrial Relations. For the details of this episode, see id. at 15-22. 
tions. Supported by the AAA, the industry concluded that the entire citrus belt was within the area of production. Responding to complaints from unions representing packing house workers, staffers on the advisory board declared that their definition was not intended to exclude these workers from the scope of codes under the NIRA. A revision was issued which altered the disputed phrase to "on the farm."

The AAA refused to accept this revision and insisted that the original definition was "official" since it had been approved by both administrative agencies (AAA and NRA). Moreover, the AAA proceeded to negotiate marketing agreements in Florida, Texas, California and Arizona citrus areas without reference to NIRA labor codes. ${ }^{40}$ Within a couple of months, faced with this fait accompli which had clearly been supported by the Administration, the NRA reaffirmed the original definition, even though this excluded several thousand industrial-type workers from the benefits of NIRA..$^{50}$ The AAA was thus able, over the objection of NRA officials, to impose the adoption of an extremely artificial definition of agricultural labor. Under it classification would depend entirely on the location of the work site, and not at all on the nature of the work involved. ${ }^{51}$ It is inconceivable that this inter-agency conflict would have been resolved as it was without the firm support of the Administration.

The basic policy of accommodation of dominant interests to obtain their voluntary support and cooperation in recovery programs is plainly

48 NRA Release No. 692, Sept. 8, 1933, cited in Woodbury, supra note 33, at 19. "When workers are employed in processing farm products or preparing them for market, beyond the stage customarily performed on the farm, such workers are not to be deemed agricultural workers." (Emphasis added.)

49 While officials of both the NRA and AAA had signed the original definition, it appears that no executive or administrative order had been issued which would have made it official government pohicy. Section $8(\mathrm{~b})$ of the NIRA authorized the President, in his discretion, "in order to avoid conflicts in the administration of the Agricultural Adjustment Act," to delegate his code making function to the Secretary of Agriculture with respect to trades and industries "engaged in the handling of any agricultural commodity or product thereof . . ." 48 Stat. 199-200. Under this clause the citrus industry had been transferred to the AAA for code purposes.

50 There were 30,000 members in the United Citrus Workers of Florida by late 1933, including both field and packing-house employees. The AFL began orgamizing locals in this area about that time, apparently only as fact-finding agencies. They were, according to AFL representatives, in competition with UCW and "'entirely out of sympathy' with the new movement." See Jamieson, supra note 8, at 330-34.

51 This irrational method of classification has been continued to this date in the Fair Labor Standards Act, 52 Stat. 1060 (1938), as amended, 29 U.S.C. \$\$ 201-19 (1964). Section 13 exempts from $\S \S 6$ (minimum wages) and 7 (maximum hours) "any individual employed within the area of production (as defined by the Secretary [of Labor]), engaged in handling, packing, storing . . . or canning of agricultural or horticultural commodities for market. .. " 52 Stat. 1067 (1938), as amended, 29 U.S.C. \$ 213 (a) (10) (1964). (Emphasis added.) A phrase, the origin of which was really a mistake, has thus had an incredibly long life. 
evident here. However contrary to the spirit and language of the NIRA, and however disappointing to the workers involved, the Administration refused to uphold a position unacceptable to the citrus industry. While agriculture's political power manifestly influenced this decision, it would be inaccurate to conclude that it alone shaped the ultimate solution. Organized labor failed to contribute any support to the citrus workers at all. This failure to object was strikingly demonstrated when the Wolman definition was reaffirmed. George Berry, the Deputy Administrator who approved it for the NRA and a one-time member of the AFL's Executive Council, ${ }^{52}$ signed it without any apparent disapproval or reluctance-an inconceivable situation had the workers involved been within the craft or trade structure of the AFL. Although a contrary course of action might have had little effect on Administration policy, this silence, whether a result of indifference, ignorance, or preoccupation with other problems, ${ }^{53}$ coupled with the ineffective and neghigible extent of organization among farm workers, certainly made it easier for the Administration to go along with the citrus industry. The same failure to speak out contributed, at least to some extent, to the ease with which agricultural labor was excluded from the National Labor Relations Act.

\section{II}

\section{EXCLUSION OF AGRICULTURAL LABOR FROM THE NATIONAL LABOR RELATIONS ACT ${ }^{54}$}

The legislative history of the National Labor Relations Act demonstrates that neither Congress nor virtually anyone else was concerned with the problems of agricultural labor. ${ }^{55}$ Senator Wagner's original bill, ${ }^{56}$ introduced only a month after the NRA had capitulated to the AAA

52 Berry had also been a past president of the International Printing Pressman and Assistant's Union.

53 It is difficult to attribute the silence to ignorance considering the AFL's action in the Florida citrus area. See note 50 supra. Labor was having a problem getting \$ 7(a) benefits even for industrial workers. The steel and automobile industries especially were stubbornly refusing to implenent its provisions, and were ignoring suggestions of the $\mathrm{Na}$ tional Labor Board, headed by Senator Robert Wagner, aimed at settling disputes arising out of $\$ 7$ (a). The inability of the Board to gain compliance with its orders prompted Senator Wagner to introduce his labor-disputes bill, which eventuated in the National Labor Relations Act. TAFT, op. cit. supra note 38, at 420-21.

54 See note 2 supra.

55 The one exception was Representative Vito Mareantonio; his advocacy of including agricultural workers within this legislation is not without irony, considering the urban nature of his constituency and his political interests. See text accompanying note 68 infra. No one appeared to represent farn workers during any of the hearings on the labor bills.

56 S. 2926, H.R. 8423, 73d Cong., 2d Sess. (1934). See NLRB, Legtstative History or the National Labor Retations Act 1-14, 1128-40 (1949). 
regarding the definition of agricultural labor, ${ }^{57}$ would clearly have applied to farm workers as initially drafted. ${ }^{58}$ A little over two months later, however, when the bill was reported out of committee, the term "employee" had been redefined, without explanation, ${ }^{60}$ to exclude "any individual employed as an agricultural laborer . ..."

Only the Senate Committee on Education and Labor held hearings on the Wagner bill in 1934. There was no more than a parenthetical reference to the agricultural situation; the committee was preoccupied with the company union phenomenon which liad had a spectacular developinent under the NIRA. ${ }^{01}$ Dr. William Leiserson, an authority on labor problems, speaking of possible difficulties in attempting to cover small employers, suggested: "You might want to except a small farmer with a few employees, but you certainly would not want to except him in a situation like the one you have out in the Imperial Valley now, with a great number of people working in agricultural employment."22 Senator Walsh, the committee chairman, replied: "As the bill is drafted, there is no limitation at all." ${ }^{\text {"63 }}$ What happened between the moment of this

57 In spite of the definition it had finally agreed to (NRA Release No. 2781, Jan. 17, 1934, cited in Woodbury, supra note 33, at 20), when negotiating a code for the cotton ginning industry, the Advisory Council of the NRA recommended this guideline: "[T]he status of an agricultural worker becomes that of an industrial worker whenever he leaves the land and enters any plant, factory, or other establishment in which agricultural products are processed or prepared for the market." Woodbury, supra note 33 , at 21 . The interdepartmental study (see text aceompanying note 41-42 supra), which intimated that agricultural labor as such might be covered by the NIRA and that a code might be imposed on the industry, had not yet been completed.

68 S. 2926, 73d Cong., 2nd Sess., § 3(3) (1934), defined "employee" as "any individual employed by an employer ... [including persons whose work had ceased] as a consequence of, or in connection with, any current labor dispute." The only exclusion applied to an "individual who has replaced a striking employee." NLRB, op. cit. supra note 56, at 2. For an identical reading in the House bill, see id. at 1129.

59 S. Rep. No. 1184, 73d Cong., 2d Sess. 1 (1934): "As now drafted, the bill does not relate to employment as a domestic servant or as an agricultural laborer." No reasons were offered for the change.

69 This is the language still to be found in the National Labor Relations Act, § 2(3), 49 Stat. 450 (1935), 29 U.S.C. \& 152(3) (1964).

61 The failure of $\S 7$ (a) to prevent the rise of the company-donninated umion was undoubtedly the chief reason that Senator Wagner sponsored the Labor-Disputes Bill. "My six months experience as Chairman of the National Labor Board . . . indicates that the weaknesses in section 7 (a) should and can be cured. That is the object of the present bill .... The greatest barrier to freedom is the employer-dominated union, which has grown with amazing rapidity since the passage of the Recovery Act." NLRB, op. cit. supra note 56, at 38-39. At least as many company urions were formed after NIRA as those not under company domination. See NaTtonal INDUSTRIAI Conference BD., IndivmUaL AND Collective Bargatning UNDER THE NIRA (1938).

62 NLRB, op. cit. supra note 56, at 269. (Emphasis added.)

63 Id. at $1155 \mathrm{~A}$. 
exchange and May 26 when the bill, having been redrafted to exclude the farm worker, was reported out of committee? We can gain no clues from congressional action on the bill in 1934, which was passed over as too controversial. ${ }^{84}$

In 1935 both Senate and House committees conducted hearings on the re-introduced bill. ${ }^{65}$ Again agricultural labor was hardly discussed. ${ }^{86}$ The agricultural exclusion was not considered at all in either the hearings or the debate in the Senate. The Senate report, however, mentioned one reason for the exclusion: It was deemed wise for "administrative reasons." ${ }^{37}$ The minority report of the House Committee on Labor, on the

64 The absence of Administration support for the Wagner bill is evidenced in this comment of Representative Peavey: "The general sentiment prevailing is that the administration is opposed to the measure and that it will not be considered at this session, unless consideration is forced by discharge of the committee." Id. at 1144. Representative Connery, who had introduced the Wagner bill into the House, was opposed to an attempt to force this discharge. President Roosevelt's lack of support for the Wagner Act is well knowm. Frances Perkins, Secretary of Labor at the time, gave all credit to Senator Wagner, stating: "It was not a part of the President's program. It did not particularly appeal to him when it was described to him." Perkins, The Rooseveti I KNEw 239 (1946). According to Irving Bernstein, who researched the inatter thoroughly, Roosevelt was never really interested in collective bargaining legislation, either in the NIRA ( $\$ 7(a)$ ) or the Wagner Act. Bernstenn, The New Deal Collective Bargatning Policy 25, 56, 89, 114-16 (1950). His last-minute support was somewhat forced by considerable political pressure: the need of Wagner's influence on other pieces of legislation. Fleming, The Significance of the Wagner Act, in Labor AND THE NEW DEAL 128 (Derber \& Young ed. 1961).

${ }^{65}$ S. 1958, H.R. 6288, 74th Cong., 1st Sess. (1935). The Senate Committee on Education and Labor and the House Committee on Labor conducted the hearings. The movement in favor of these bills had been greatly stimulated by the failure of Public Resolution 44 to accomplish its extremely limited objectives. The latter, an Administration package substituted for the Wagner bill in the closing moments of the 1934 session, permitted investigation into controversies arising under $\S 7$ (a) of the NIRA. The National Labor Relations Board, which was established to do this job, was practically impotent, meeting with "the refusal of employers to attend hearings . . . [its orders being] frequently ignored or challenged in the courts." TAFr, op. cit. supra note 38 , at 456-57.

66 There was only an indirect reference to the field which came from the testimony of James Rorty, a New York Post reporter, who had attempted, unsuccessfully, to cover a strike of lettuce workers in the Imperial Valley. His remarks, however, were confined almost exclusively to the peculiar experience he had with local police, who escorted him unceremoniously to the Arizona border. Rorty undoubtedly played a prominent part, thereafter, in establishing the reputation of the Imperial Valley as "one of the most highly publicized localities in the country for its suppression of civil liberties." Jamieson, Labor Unionism in American Agriculture, in U.S. BUREAU OF LABOR STATISTICS, DEP'T OF Labor, BULL. No. 836, at 108 (1945). The strike Rorty hoped to cover was not held by field workers, but rather by lettuce packers who migrated from crop to crop. Their organization, the Vegetable Packers Association No. 18211, had some success in 1934 around Salinas, California, but their efforts in the Imperial Valley failed. Id. at 137-38. For an account of Mr. Rorty's adventure, see NLRB, op. cit. supra note 56, at 2501-25.

67 Id. at 2306. The same reason was stated for excluding domestic servants and persons employed by parents or spouse. 
other hand, made an inpassioned plea for the inclusion of farm labor, a bid which was repeated by Representative Marcantonio, the author of the report, on the House floor during the debate on the measure:

I, therefore, respectfully submit that there is not a single solitary reason why agricultural workers should not be included under the provisions of this bill. [The same reasons urged for the adoption of this bill in behalf of industrial workers] are equally applicable in the case of agricultural workers, in fact more so as their plight calls for immediate and prompt action. ${ }^{.8}$

During the House debate on the bill Marcantonio offered an amendment striking out the exclusion. It was defeated after Representative Connery, the bill's sponsor and chairman of the Labor Committee, objected:

[T] he committee discussed this matter carefully in executive session and decided not to include agricultural workers. We hope that the agricultural workers will be taken care of. . . I am in favor of giving agricultural workers every protection, but just now I believe in biting off one mouthful at a time. If we can get this bill through and get it working properly, there will be opportunity later, and I hope soon, to take care of the agricultural workers. ${ }^{69}$

This objection was no more than an echo of the "administrative reasons" excuse found in the Senate report. Connery's reference to getting the bill through may have been a hint at the political realities which, while not mentioned openly, were certainly present and operating during the consideration of this bill.

Agricultural workers were excluded during this same session from the Social Security bill; and administrative difficulties again provided the basis for the exclusion. ${ }^{70}$ The decision to exclude was made during an

68 H.R. REP. No. 969, 74th Cong., 1st Sess. 27-28 (1935). Appended to the end of the oral hearing record of the House Committee on Labor were several pages of materials dealing with strikes in agriculture and other related matter. NLRB, op. cit. supra note 56, at $2816-41$.

69 Id. at 3202. Only Representative Boileau of Wisconsin actually spoke against coverage for agricultural workers: "[I] $\mathrm{t}$ would be very unfortunate to permit the organization of casual farm employees." Fie did not add any comment as to why it would be unfortunate. Representative Ellenbogen was for coverage if Congress had the power, but no one argued one way or the other on this point, at least in relation to agriculture. No one claimed that agriculture was strictly intrastate commerce, therefore beyond the jurisdiction of Congress which extends only to the regulation of interstate commerce. A delicate political balance is suggested by the following exchange between Representatives Knutson and Connery: The former asked if Connery's remarks carried "the inference that ultimately under this legislation it is proposed to organize agricultural laborers?" Connery hastened to reply: "I did not say exactly that." But he hoped they would organize just as industrial workers. Knutson answered: "For the time being? That is all I wanted to know." Id. at 3203.

70 "No systematic consideration of the advisability or feasibility of covering agricultural labor was undertaken in hearings or debates on the Social Security Act of 1935. . . [The 
executive session of the House Ways and Means Committee. Dr. Edwin Witte, Director of the Economic Security Committee which played a major role in drafting and conducting this legislation through Congress, was present at these sessions. His comments make it clear that political considerations had a good deal more to do with this exclusion than possible problems with administration: "In taking this position, the committee apparently was influenced far less by the difficulties of administration than by the fact that it was felt that the farmers would object to being taxed for the old age insurance protection for their employees."71

Congress, traditionally responsive to agricultural and rural needs, ${ }^{72}$ was quite capable of killing the whole Social Security bill if this "felt" objection was not insured against by excluding agricultural workers from coverage. Political realities dictated this course of action whatever the merits of the administrative-difficulty thesis. The interesting point, however, is that the prominent use of this theory obscured the fact that Congress was apparently far less concerned about this kind of obstacle than it was about the very real agricultural opposition to the Social Security bill. It would be unrealistic to suppose that a similar influence did not play a dominant part in effecting the exclusion of agricultural laborers from the Wagner Act. ${ }^{73}$ Administrative complexities have not

question arose] almost casually and usually was brought up by people who, for one reason or another, were opposed to the bill and not primarily interested in social security for agricultural workers." Ross, supra note 26, at 120. WrTte, Development of the SoctaI. SECURITY ACT (1962) (published after the author's death, but prepared immediately after passage from extensive personal notes) reports that the Treasury Department was especially concerned about administration of a program that would depend for its funds on pay-roll tax collections. Subordinate officials convinced Secretary Morganthau this would be administratively impossible with agricultural workers. Id. at 153 . Even the friends of labor assumed that it was administratively impracticable to include agricultural labor. Ross, supra note 26, at 120. And the NAACP thought no argument was necessary to prove that the overhead in administering a program for domestic, casual and agricultural workers would consume the tax itself. Id. at 121 .

71 WrTte, op. cit. supra note 70, at 153. (Emphasis added.)

72 Writing on Congress' sensitivity to labor's problems during the New Deal, Murray Edelman refers to certain "well recognized institutional characteristics of the Congress." Both House and Senate "greatly underrepresent urban areas," and constituency pressures are exerted disproportionately on behalf of farmers and local industries rather than the urban worker. The Depression, however, generated massive public enthusiasm for reform and "amehorating the lot of the unemployed and imposing government regulations upon business discretion in labor matters." This was especially mamifested by the "highly atypical" midterm victory for the Democrats in the 1934 elections. While Congress reflected the pubhic interest in enacting direct benefits for industrial labor during the years from 1931 to 1935 , most of which passed both houses with considerable majorities, "not even the chmate of the early New Deal could surmount overriding congressional sensitivity to the agricultural organizations . . . " Edelman, supra note 30, at 188.

73 Senator Wagner wrote to Norman Thomas that the opposition of the farm bloc made coverage of agricultural labor under his bill out of the question. See Hearings Before the Subcommittee on Migratory Labor of the Senate Committee on Labor and Public Welfare on 
been known to over-awe Congress; they can become very convenient shields for inaction.

The exclusion of agricultural labor from the NLRA without public hearings, discussion or debate on the merits is not extraordinary considering the sensitivity of Congress to agricultural sentiment-which was well known to be solidly opposed to unionism-and the failure of any one, in or out of Congress, to force a dialogue on the issues involved. There was therefore no need for agricultural interests to justify their opposition before the public with any kind of reasoned argument. The position of agriculture thus contrasts sharply with industry's massive efforts to persuade Congress and the nation that the Wagner bill was not only unnecessary but seriously injurious to the public welfare. ${ }^{74}$ Ironically, the NLRB was the agency which eventually impelled agriculturalists to formulate a rational basis for their position against labor legislation..$^{75}$

\section{III}

\section{THE NATIONAL LABOR RELATIONS BOARD AND AGRICULTURAL LABOR}

Considering the sharp dispute between NRA and AAA officials over an acceptable definition of agricultural labor, it is almost incredible that no one suggested sucl a definition for the NLRA. ${ }^{70}$ When the scope of the exclusion finally-and inevitably-became an issue, the Board had

S. 1864, S. 1865, S. 1866, S. 1867, S. 1868, 89th Cong., 1st \& 2d Sess. 463 (1966) (testimony of Benjamin Aaron, Professor of Law and Director of the Institute of Industrial Relations, University of California at Los Angeles).

74 The opposition did not end with the passage of the act; it was not immediately accepted because its constitutionality was seriously doubted by some lawyers. "[C]onsidering the Act in the light of our history, the established form of government, and the decisions of our highest court, we have no lesitancy in concluding that it is unconstitutional and that it constitutes a complete departure from constitutional and traditional theories of governnient." Nattonal Lawyers Comar. of AMERrchin Liberty League, Report on the Constitutionatity of tee National Labor Relations ACt x-xi (1935).

75 It has been said that "considerations associated with the hired man on the family farm have nade social legislation seem inappropriate for agriculture. ... [His] employment status has thrown doubt on the need for collective bargaining ...." Ross, supra note 26, at 93. Lumping domestic servants, persons employed by parent or spouse, and agricultural laborers in one broad exemption from the NLRA seems to bear this out. Congress refused, however, to exempt employees in small employer units. The committee report explained this refusal: "But after dehberation, the committee decided not to exclude employees working for very small employer units [10 or less]. The rights of employees should not be denied because of the size of the plant in which they work." S. REP. No. 573, 74th Cong., 1st Sess. 7 (1935). (Emphasis added.) The logic of this declaration certainly applies to small employer units which inay happen to he engaged in agricultural production.

76 The Social Security Act, as originally passed, also included the term "agricultural labor" without defining it. 49 Stat. 625 (1935). A lengthy definition was subsequently added to the act. See note 138 infra. 
to interpret the act aided only by that sometimes nebulous guideline of congressional intent.

It was not until after the constitutionality of the NLRA had been established $\mathrm{d}^{77}$ that the Board considered a case requiring an interpretation of the agricultural exemption. In the fall of 1937 the Citrus Packing House Workers filed unfair labor practice charges against the North Whittier Heights Citrus Association. ${ }^{78}$ The Association challenged the Board's jurisdiction, inter alia, on the ground that their employees were all agricultural laborers. This jurisdictional objection was supported by two basic contentions: The first was based on the industry's own body of opinion as to the nature of the work force involved; the second was an attempt to persuade the Board that Congress had intended the agricultural exclusion to extend to these packing house employees.

Four grounds supported the assertion that the packing employees were agricultural laborers within the meaning of the NLRA exclusion: 1) The "customary and accepted meaning" of agricultural laborers within the industry included packing house workers; 2) it was "quite general in the industry to interchange labor between the packing house and activities in the fields ...;"3) the packing house operation was once "in the history of the industry performed on the farm by the farmer himself ...;" and 4) the Association's employees "must be considered agricultural the same as if employed by the orchard owner" since the Association was merely the agent of the affiliated growers. ${ }^{79}$ The first two arguments failed for lack of proof. ${ }^{80}$ The third, that since the packing

77 NLRB v. Jones \& Laughlin Steel Corp., 301 U.S. 1 (1937). There can be no doubt but that the Board was extremely cautious about the kind of case it would consider until the question of constitutionality had been settled. See, e.g., I NLRB ANN REP. 135-37 (1936).

It is also true, however, that umon activities in the citrus industry in California did not really begin to develop seriously until 1937-1938. "Organizational advances for several years [previously] were somewhat nullified by interumion rivalries." Jamieson, supra note 66 , at 168 .

78 North Whittier Heights Citrus Ass'n, 10 N.L.R.B. 1269 (1939).

70 Id. at 1277 .

80 While many persons, including state employees, testified to the "common usage" which viewed these employees as agricultural labor, there was no "showing made of any specific instance in which this definition was ever used or was ever appled." Ibid. As a matter of fact, the Califormia Unemployment Reserves Commission promulgated rules on February 14, 1937 to the effect that "non-profit cooperative packing houses are usually operated by groups of farmers and, although packing is carried on exclusively for members, labor employed by such non-profit cooperative packing associations is not exempt . . . as 'agricultural labor." "Id. at 1282. The Association could not demonstrate that interchange was more than a rare event that usually occurred only during emergencies. It was customary for everyone to turn out during times of frost to belp with the heating and smudging in the orchards. The Board ruled that emergency activities "cannot serve to bring the employees under a classification corresponding to such emergency work." Id. at 1278 n.7. 
operation was once agricultural in nature, it must continue to be so, provided the Board with an occasion to refer to the changes which had occurred within the industry. "The organization of individual orchard owners into cooperative marketing associations has led to highly efficient and mechanical methods in packaging the crop. In the light of such changes in packing methods it is idle to argue that no change in the character of the labor of packing workers can have taken place." ${ }^{181}$ The fourth argument was denied because the assumption on which it was based, that employees of an agent must be considered employees of the principal, was "without merit."

The Association's second basic contention-that Congress intended these packing house workers to be within the general agricultural exclusion-was based on an analysis of the then recently enacted Fair Labor Standards Act. ${ }^{83}$ Upset over administrative rulings on the meaning of agricultural labor promulgated under the Social Security Act, ${ }^{84}$ and even

81 Id. at 1278-79.

82 The Board was in some doubt as to whether an agency relationship had actually been established, despite the terminology of the corporate documents. The Association was empowered by its by-laws to "picls, transport, receive, process, handle, pack, ship, sell and transfer title to said fruit at such time, or times, and in such markets and for such amounts as the Association shall deem best, and by and through such agent or agencies as the Association may select or provide. The time or times when fruit shall be picked for marketing shall be determined in accordance with general rules to be established by the Board of Directors which may be changed from time to time. The Association may enter upon the lands where any fruit is grown without previous demand or notice to the member, and pick the same at the time or times when the same should be picked, and transport the same to the packing house of the Association, and process, pack, ship, and sell the same, and do each and every act and thing by the Association decmed necessary or desirable in connection with the preparation for market and disposition of said fruit. Id. at 1279. The Board refused to concede, since the facts of the case did not require it, that packing workers employed directly by the orchard owner were agricultural laborers.

83 Fair Labor Standards Act, 52 Stat. 1060 (1938), as amended, 29 U.S.C. \$§ 201-19 (1964).

84 The United States Treasury Department, Bureau of Internal Revenue and the Social Security Board issued identical regulations defining the "agricultural labor" exemption: "The term ... includes all services performed-(a) By an employee, on a farm, in connection witb the cultivation of the soil, the raising and harvesting of crops, or the raising, feeding or management of livestock, bees, and poultry; or (b) By an employce in connection with the processing of articles from materials which were produced on a farm; also the packing, packaging, transportation, or marlseting of those materials or articles. Such services do not constitute agricultural labor, however, unless they are performed by an employee of the owner or tenant of the farm on which the materials in their raw or natural state were produced, and unless such processing, packing, packaging, transportation, or marketing is carried on as an incident to ordinary farming operations as distinguished from manufacturing or commercial operations." 1 Fed. Reg. 4-5 (1936) (Treasury Department); 1 Fed. Reg. 1767 (1936) (Internal Revenue Service); 2 Fed. Reg. 1278 (1937) (Social Security Board). (Emphasis added.)

Under these regulations the Bureau of Internal Revenue had ruled that services performed by individuals employed by an association of producers were not exempted under 
more apprehensive about the kind of action the NLRB might be expected to take, ${ }^{85}$ agricultural producers finally persuaded Congress to give some attention to drafting an acceptable definition of the controversial term. ${ }^{86}$

the act, whereas the same services performed for an owner or tenant would be. The Bureau reasoned that employees of an association were not exempt because they were "not [employees] of a particular producer." North Whittier Heights Citrus Ass'n, 10 N.L.R.B. 1269, 1284 (1939).

The obvious advantages given to the large grower-packers by this ruling gave rise to complaints of discrimination. The Bureau then investigated the operation of a Yuma, Arizona lettuce grower-shipper, and decided it was taxable. The new ruling ended the discrimination, but the complaints grew more serious: "[These rulings have] removed the last vestige of what we beheve to be the correct interpretation of the term 'agricultural labor,' and at the same time . . . candidly revealed that the Treasury Department have in mind actual tillers of the soil as their version of agricultural labor." Western Grower and Shipper, July 8, 1937, p. 17 .

A prompt letter to Guy Helvering, the Commissioner of Internal Revenue, brought about a restoration of the original rule-and the discriminatory treatment. Dissatisfaction with these rulings, claimed to be far from Congress's original intention, moved agricultural associations, particularly representatives of the fruit and vegetable industry, to seek legislative protection from this allegedly arbitrary and capricious administrative treatment. See Ross, Agricultural Labor and Social Legislation 124-31 (1941) (unpublished thesis in the University of Califormia, Berkeley, Library).

85 There can be little doubt but that "the central impulse [behind these efforts to obtain a defimition of agricultural labor] probably has been a desire to remove fruit and vegetable packing workers from the protection of the National Labor Relations Act." Ross, supra note 84, at 221. The Agricultural Producers Labor Committee (APLC) was organized in July of 1937 to spearhead these efforts. Ibid. It had no other purpose than "relieving agriculture from the requirements of federal legislation regulating labor," according to Ivan McDamiel. Id. at 224. McDamel, the group's attorney also represented the North Whittier Citrus Association before the NLRB.

The APLC appears to have been a cover organization for the Associated Farmers which had been formed for one reason "to break farm-labor unionism and suppress strikes by means of more or less 'direct action'." Jamieson, supra note 66, at 40 . The new group also represented the Califorma fruit and vegetable packing industry which led the movement to broaden the definition of agricultural labor. Ross, supra note 84, at iii, 219-20. The Associated Farmers had built up a bad reputation in Washington because of its strikebreaking activities. The California Fruit Growers Exchange (CFGE), of which the Whittier Association was a member, could not afford to "come out in the open on the labor issue." Id. at 221.

ALPC was led by W. E. Spencer, a director of both the Associated Farmers and CFGE. Months before the NLRB decided the Whittier case, Spencer, speaking to the State Cliamber of Commerce, declared: "Some united action was necessary on the part of employers of this type of labor [packing louse] if the complete umonization of farm labor under the jurisdiction of the NLRB was not to be accomplished." Id. at 225.

88 The original bill (S. 2475, 75th Cong., 1st Sess. (1937)) excluded "any person employed ... as an agricultural laborer as such terms are defined and delimited by regulations of the Board [administering FLSA]. Fruit and vegetable spokesmen were not satisfied with this. Convinced that the Social Security regulations had defined the term in an arbitrary, capricious and discriminatory manner' they wanted 'farmers . . . protected from a repetition of this treatment' by having Congress do the job. The watchword of their campaign was that the agencies had 'perverted the intent of Congress through insufficient liberality in delimiting the exemption and that Congress must reassert its purpose through legislative amendment." Ross, supra note 84, at 177 . 
The FLSA, besides defining agriculture broadly, specified the employment exemption precisely:

Sec. 3. As used in this Act-

(f) "Agriculture" includes farming in all its branches and among other things includes the cultivation and tillage of the soil, dairying, the production, cultivation, growing, and harvesting of any agricultural or horticultural commodities (including commodities defined as agricultural commodities in section $15(\mathrm{~g})$ of the Agricultural Marketing Act, as amended), the raising of livestock, bees, fur-bearing animals, or poultry, and any practices (including any forestry or lumbering operations) performed by a farmer or on a farm as an mcident to or in conjunction with such farming operations, including preparation for market, delivery to storage or to inarket or to carriers for transportation to market.

Sec. 13(a) The provisions of sections 6 and 7 [relating to wages and hours] shall not apply with respect to ... (6) any employee employed in agriculture; or ... (10) to any individual employed within the area of production (as defined by the Administrator), engaged in handling, packing, storing, ginning, compressing, pasteurizing, drying, preparing in their raw or: natural state, or canning of agricultural or horticultural commodities for market, or in making cheese or butter or other dairy products. ${ }^{87}$

Claiming that these clauses represented what Congress intended to exclude from the NLRA, the Citrus Association believed it had two avenues of escape: The packing operation should be held to be one of the "practices ... performed by a farmer ... as an incident to ... such farming operations," and therefore "agricultural" employment under section 3(f); or, one involving "handling, packing, storing ... of agricultural . . . commodities for market," and therefore within the exemption of section 13 (a) (10). ${ }^{88}$ The Board rejected both contentions on rather technical grounds: "We think it plain that the ... provisions of the Fair Labor Standards Act of 1938 are prevented from applyimg to 'any individual employed within the area of production ...'by an express statu-

California's Associated Farmers suggested this definition: "[A]griculture in all its branches and any work usually performed by a farmer on a farm, and any work incidental to farming operations, including the processing, packing and preparation for market... when performed by the farmer or by a farmer owned and controlled cooperative and all labor employed in the area of production in the harvesting and preparing for delivery to market of any dairy product, or of any other agricultural product in its raw or natural state." Id. at 179. (Emphasis added.)

87 Fair Labor Standards Act $\S \S 3(f), 13(a)(6)(10), 52$ Stat. 1060, 1067 (1938), as amended, 29 U.S.C. $\S \S 203($ f), $213(2)(6)(10)(1964)$.

88 This approach was employed particularly when the Whittier Association alleged that, since packing of citrus had once been done in the field by the same persons who picked the fruit, it must continue to be an incident to ordinary farming practices. The position was supported by arguing that the Association was merely the agent of the farmer-memhers. See text accompanying note 79 supra. 
tory exemption and not because such an individual is considered as being employed in agriculture. ${ }^{189}$ Refusing to rule that the packing operation was an incident to the farm operation, the Board merely declared that the FLSA definition was "consistent with the definitions of 'agricultural labor' and 'agricultural laborer' applied by the Treasury Department and the Social Security Board, and the Bureau of the Census."

The citrus industry must have been alarned to learn that, as far as the NLRB was concerned, the FLSA did no more than perpetuate the regulations promulgated under the Social Security Act. This alarm was intensified by the Board's singular interpretation of those regulations in a case involving lettuce workers, ${ }^{91}$ a case decided a little more than a month earher than Whittier.92 While approving the regulations in this earlier decision as "an adequate interpretation which may be applied to the term 'agricultural laborer,' as used in Section 2(3) of the National

${ }^{80}$ North Whittier Heights Citrus Ass'n, 10 N.L.R.B. 1269 (1939). The Board relied for this interpretation of congressional intent on the fact that FLSA, as enacted in 1938, was not quite the same as the version which was passed by the Senate in 1937, but was recommitted to the Labor Committee in the House. Before recommitment the House adopted the following amendment: "The term 'person employed in agriculture' ... shall include persons employed within the area of production engaged in preparing, packing, or storing agricultural commodities in their raw or natural state, and shall include persons employed by any cooperative association ... if engaged in preparing, packing, or storing agricultural commodities ...." S. 2475 , 75th Cong., 1st Sess. $\$ 2$ (a)(20) (1937). This amendment broadened the Senate bill which provided that the term "person employed in agriculture" ... insofar as it shall refer to fresh fruits or vegetables, shall include persons employed within the area of production engaged in preparing, packing, or storing such fresh fruit or vegetables in their raw or natural state," and which did not specifically exempt employees of cooperative associations. The finally approved draft not only reflects the original Senate bill, but merely exempts "any individual employed ... etc.", eliminating the language specifying such an individual as a "person employed in agriculture." Id. at 1283-84. See test accompanying note 87 salpra.

While it is fairly certain that Congress was opposed to excluding all cooperative packing establishments, irrespective of their location, it is not at all certain that the legislators intended to draw a distinction between agricultural laborers and individuals employed in processing agricultural commodities in their raw or natural state. It may have been a result of careless drafting which the NLRB was quick to seize upon.

9010 N.L.R.B. at 1284. See note 84 supra for these regulations. The Board's analysis of FLSA seems quite accurate. The regulations defining "agricultural labor" under the Social Security Act included "services performed ... in connection with the processing of articles from materials which are produced on a farm" only if these services were performed by employees of "the owner or tenant of the farm on which the materials in their raw or natural state were produced." FLSA exempted anyone employed in agriculture, which in turn was defined as including "any practices ... performed by a farmer or on a farm as an incident to or in conjunction with such farming operations, or packing associations." This, of course, ignores the specific exemption of processing workers contained in $\S 13(a)(10)$ (see text accompanying note 87 supra), technically legitimate because of the failure to define the packing operation as specifically agricultural.

01 American Fruit Growers, 10 N.L.R.B. 316, 328 (1938).

9210 N.L.R.B. 1269 (1939). 
Labor Relations Act," the Board nevertheless departed from the manner in which they had been applied by the issuing agencies.

Some of the lettuce workers were employed by owner or tenant growers who did their own processing. These workers were expressly exempted from the scope of the Social Security Act by reason of the administrative rulings of the agencies responsible for enforcing that act. ${ }^{.3}$ To come within the exemption, the Social Security regulations required that the workers be employed by a farmer-owner or tenant, and that the work be "an incident to ordinary farming operations as distinguished from manufacturing or commercial operations." While the Social Security agencies thus assumed that lettuce packers satisfied this latter condition, the NLRB in the lettuce case ruled that they did not: "It is our conclusion that the services which are performed by shed workers engaged in the packing and shipping of lettuce are not 'agricultural' in nature, but are performed in connection with commercial packaging and shipping enterprises." 105

A unique feature in Whittier was the NLRB's refusal to be bound by the peculiar administrative policies on agriculture that had begun under the NIRA. ${ }^{96}$ Since that time, workers' classification as agricultural had depended on irrelevant tests of job locality or the employer's tenure relationship to the land.97 Incredibly, the kind of work being done had nothing to do with the classification. The Board's rejection of those

\footnotetext{
03 See note 84 supra.

94 Ibid.
}

9510 N.L.R.B. 316,329 (1938). The Board expressly refused to be bound by all "the specific rulings which have been made ..." and rejected Commissioner Helvering's agreement to exempt lettuce packer-growers, see note 84 supra, an agreement which overruled his own agency. "In our opinion [Board], this ruling [Helvering's] is based upon an incomplete statement of facts which are more fully revealed in this proceeding and, furthermore, overlooks the requirement that the packaging must be carried on "as an incident to ordinary farming operations ...." Helvering scems not to have overlooked this point, however, for his letter of agreement refers to "packing operations [which] are an integral and dependent part of the farming operation." 10 N.L.R.B. at 328 n.13. Ross, supra note 84 , at 127 , says that from the time of Helvering's ruling, the grower-shippers operations were regarded as incident to farming, at least by the Bureau of Internal Revenue.

${ }^{96}$ See text accompanying notes 46-50 supra.

07 The Wolman definition, discussed in note 47 supra, initiated this arbitrary method of classification by ruling that processors of farm products, whatever the kind of work involved, would be considered "agricultural labor" if employed on a "stage customarily performed within the area of production." It should be noted that the artificial nature of this definition was not eliminated by the NRA's fruitless efforts to substitute the phrase "on the farm" for "area of production." The locale of processing labor should not control; the nature of the work should. Indeed, the guidelines adopted under the NIRA appear to be behind the Social Security regulations which exempted the grower-packer but not the independent processor, whose employees were engaged in exactly the same kind of work and employment relationship. 
totally arbitrary and discriminatory guidelines and its determination to base its decision on the characteristics of the packing operation signaled a new approach to labor relations in agriculture. The Citrus Association's contention in Whittier that its work force was "agricultural labor" was denied on appeal to the Ninth Circuit. ${ }^{98}$ Arguing from the act's basic policy, Judge Stephens held that what Congress intended by the term "agricultural laborer" was "not at all obscure," and that there was a "common denominator" underlying the act's exclusions." Asking why an individual employed by his parent or spouse was exempted, ${ }^{100}$ the judge answered: "Because (not excluding other reasons) in this classification there never would be a great number suffering under the difficulty of negotiating with the actual employer and there would be no need for collective bargaining and conditions leading to strikes would not obtain."101 Convinced that the same reasoning appled to domestic service and agricultural labor if the latter term was "not enlarged beyond the usual idea the term suggests," Judge Stephens could not find the "common denominator" underlying the act's exemptions present in the citrus packing operation:

When every detail of farming from plowing to delivering the produce to the consumer was done by the farmer and his "hired man", this common denominator was present. But when in the transition ... to the great industry of the present in which the fruit is passed ... to a corporation for treatment in a packing house owned and run by such corporation ... we think the common denominator has ceased to exist. ${ }^{102}$

${ }^{88}$ North Whittier Heights Citrus Ass'n v. NLRB, 109 F.2d 76 (9th Cir.), cert. deried, 310 U.S. 632 (1940).

90 Id. at 79-80. For the statutory statement of basic purpose, see National Labor Relations Act $\S 1$, 49 Stat. 449 (1935), 29 U.S.C. $\S 151$ (1964). See also text accompanying notes 5-7 supra.

100 Excluded from the NLRA along with agricultural laborers are individuals "employed ... in the domestic service of any family or person at his home, or . . employed by his parent or spouse ...." National Labor Relations Act \& 2(3), 49 Stat. 450 (1935), 29 U.S.C. $\$ 152(3)$ (1964).

101 North Whittier Heights Citrus Ass'n v. NLRB, 109 F.2d 76, 80 (9th Cir.), cert. denied, 310 U.S. 632 (1940).

102 Judge Stephens destroys the basis for exclusion. Logically applied, his argument destroys any support for exclusion of that kind of agricultural labor which in fact was (and still is) "suffering under the difficulty of negotiating with the actual employer," where there has long been a need for collective bargaining because the "conditions leading to strikes" are rampant. See text accompanying note 101 supra. His argument deserves the attention of Congress.

It was with some irony that the Citrus Association demanded a test to determine whether or not a practice was agricultural or industrial that would be based on the nature of the work involved. The Association argued "that if each member of the non-profit cooperative corporation ... were to personally hire and direct those doing his own packing and sorting, the work would be agricultural and his employees would be agricultural la- 


\section{AGRICULTURE TURNS TO CONGRESS}

Failing to persuade either the NLRB or the courts ${ }^{103}$ to adopt its view of congressional intent regarding the agricultural labor exemptions, farm organizations turned to Congress for legislative relief. They were forced, for the first time, to present some reasons for extending the agricultural exclusion beyond the limits set by the Board. The argument up to this point had focused on interpreting congressional intent through an analysis of the Fair Labor Standards Act and the Social Security regulations. However, to persuade congressmen what they had meant by agricultural labor, it was necessary to go into the why of the exclusion.

\section{A. The Goal: Legislative Reversal of the NLRB}

The opportunity to educate Congress presented itself in 1939 during hearings on bills to amend the National Labor Relations Act. ${ }^{104}$ Senator Logan introduced an amendment which would have defined agricultural labor broadly enough to cover practically every industry allied to agriculture. ${ }^{105}$. In support of the proposed amendment, it was urged that such

borers; that it follows, therefore, that in the case of the same members acting under a single organization to accomplish the same result there can be no change in the nature of the work nor in the status of the persons doing it." North Whittier Heights Citrus Ass'n v. NLRB, 109 F.2d 76, 80 (9th Cir. 1940). The argument was not really based on an analysis of the work involved. It is based on an assumption that if the farmer, as an individual, hired these employees, then the labor would necessarily be agricultural. This assumption is founded, apparently, on the regulations of the Social Security agencies which had rather arbitrarily ruled that processing operations for an owner or tenant of a farm would be considered agricultural, whatever the nature of the work. Judge Stephens, however, merely denied that the Association's premise was relevant because the "packing house activity is much more than the mere treatment of the fruit." Ibid.

${ }^{103}$ A petition requesting certiorari was denied by the Supreme Court, thus leaving in tact the Ninth Circuit's affirmance of the Board decision. North Whittier Heights Citrus Ass'n v. NLRB, 310 U.S. 632 (1940).

104 See Hearings on S. 1000, S. 1264, S. 1392, S. 1550, S. 1580 and S. 2123 Before the Senate Committee on Education and Labor, 76th Cong., 1st Sess. (1939).

105 S. 1550, 76th Cong., 1st Sess. (1939). This bill was to amend $\$ 2(3)$ of the National Labor Relations Act, 49 Stat. 450 (1935), 29 U.S.C. $\& 152(3)$ (1964), by adding the following paragraph:

"The term 'any individual employed as an agricultural laborer' shall include any person engaged as an employee in farming in all its branches, and among other things includes the cultivation and tillage of the soil, dairying, the production, cultivation, growing, and harvesting of any and all agricultural or horticultural commodities (including commodities defined as agricultural commodities in section $15(\mathrm{~g})$ of the Agricultural Marketing Act, as amended, and including cutting, removal, and transportation of logs, pulpwood, fence posts, fuel wood, and other primary products of farm wood lots, including the sawing of lumber from the timber of such wood lots by the farmer or by contract in which the farmer retains title to the lumber), the raising of livestock, bees, game, fur-bearing animals, or poultry, eggs, and any practices performed by or for a farmer or on a farm as 
labor was truly agricultural and that the NLRB had perverted the intention of Congress by ruling, in effect, that the only agricultural laborers exempted by the act were workers actually engaged on the farms as tillers of the soil. ${ }^{108}$ Every conceivable reason for exempting processing workers like those in Whittier was produced for congressional consideration. ${ }^{107}$

an incident to or in connection with such farming operations, including preparation for market, delivery to storage or to market, or to carriers for transportation to market; and shall also include any person engaged as an employee in connection with or incidental to the (1) cleaning, or otherwise preparing in their raw or natural state, precooling, freezing, drying, grading, packing, canning for market from their raw or natural state, of fresl fruits and vegetables; (2) ginning or compressing of cotton; (3) stripping, grading, drying, packing, stemming, or fernenting of tobacco; (4) straining, packing, separating, or otherwise preparing in its raw or natural state of honey; (5) drying, grading, baling of forage, fiber, and miscellaneous crops; (6) cleaning, packing, grading, hulling, or polishing of grains, beans, peas of all kinds, and seeds; (7) cooling, freezing, separating, packing, pasteurizing, or preparing of milk and cream; (8) making, preparing, or packing of butter, whey, and other dairy products for market; (9) receiving, grading, candling, and packing of eggs; (10) hatching of poultry, game birds, and wild fowl; (11) grading and packing of nursery and other horticultural crops; (12) shearing, grading, bagging of grease wool, mohair, and rabbit fur for market; (13) cleaning, grading, preparing, and packing nuts for market; (14) grading, local concentration, purchase, and sale of livestock for the producer; (15) drying, grading, packing, or preparing other agricultural or horticultural commodities in their raw or natural state; and such handling, storing, or refrigeration of any such commodities (but not including terminal storage or refrigeration) as is incidental thereto or used in connection therewith; when any of such operations are performed within the general territory in any region of the United States where the farming district or districts are located from which such commodity is produced and within or in close proximity to any such farming district, or at such place in the general territory in proximity to such farming district where such commodity is produced (but outside of the twenty-two leading centers of distribution as listed by the Umited States Department of Agriculture, except as to the purchase and sale of livestock), as is necessary to obtain reasonably available and adequate transportation, water, power, or other required operating facilities; and such operations are performed on products produced from any farming district within the same general territory." 84 CoNg. Rec. 1804 (1939). (Emphasis added.)

In addition to being drafted to end the Labor Board's discretion with respect to those industries closely allied to agriculture, the amendinent was also intended to indicate congressional intent regarding the "area of production." See text accompanying notes 87-88 supra. FLSA administrators had interpreted the term, after hearings at which congressmen testified concerning legislative intent, to cover plants located "in the open country or in a rural community (of less than 2,500 population)," obtaining their products "from the immediate locality (within a radius of 10 miles)." This ruling, completely unacceptable to the fruit and vegetable industry was issued March 14, 1939, only days after the Board's decision in the Whittier case. Ross, supra note 84, at 196-214.

106 See 84 Cong. REc. 1804 (1939) (remarks of Senator Logan). Senator Logan's statement explaining S. 1550 was clearly prepared by Mr. Ivan McDaniel who repeated verbatim most of the statement in his testimony before the Senate Committee on Education and Labor. See Hearings on S. 1000, S. 1264, S. 1392, S. 1550, S. 1580, and S. 2123, supra note 104, at 3623.

107 Some witnesses were careful to distinguish the exempted operations from processing work: "We prefer to calling them packing louses-they are not factories because the product still remains in its raw or natural state." Hearings on S. 1550, supra note 104, at 3627 (testimony of Ivan McDaniel). 
Since the arguments were based on the notion that this kind of work was "traditionally and actually agricultural in nature and is intimately connected with the production and harvest of the crops,"108 all of them necessarily embrace every category of agricultural labor.

Before presenting the arguments in an ascending order of importance-as judged from the frequency and emphasis with which they were proposed-one word of caution seems advisable. The witnesses representing agriculture in these hearings shared a common bias against organized labor, ${ }^{109}$ particularly those elements which had ventured into the agricultural arena. ${ }^{110}$ Moreover, the actual personal experience of some of the witnesses in this area had been limited to the strike or boycott situation. Mature labor relations involving union recognition and collective bargaining was not one of the subjects with which they had any acquaintance. ${ }^{111}$ Given their limited experience and their abhorrence

10884 CoNG. Rec. 1804 (1939) (remarks of Senator Logan).

109 "One of the most important factors in the inability of organized labor to make headway in the unionization of seasonal farm workers has been the farm employer's unswerving and complete opposition to it." Caltronnta Senate Fact Findinc Comar. on Labor and Welfare, Caltrornia's Farm Labor Problems pt. I, 202 (1961). The report equates a description of industry's attitude towards organized labor during the twenties with "that of the American and California farmers today," and quotes Bernstein: "Here was the problem of the rigidity of the American employer-of his obsessive distaste for collective bargaining and of his frequent reluctance to share the fruits of industry with his employees. . . . [H] ere, finally, was a central issue of a democratic society-whether the majority or merely a few of its members were to make its basic economic decisions." Bernstenn, The LeAn Years, A History of the AMrerican Worker, 1920-1933, at 43 (1960).

110 The witnesses agreed that "outside radical agitators" were largely to blame for their labor troubles-pointing to this or that leader as a known communist. Hearings on S. 1550 , supro note 104 , at 3633, 3670, 3692. See also 84 Conc. REc. 1806 (1939). The Communist Party's Trade Union Unity League (TUUL), "far oversbadowing all other organizations in agriculture during the early thirties," Jamieson supra note 66 at 19, declined in influence after 1934 and was formally dissolved in late 1935. The revolutionary doctrines of the TUUL were unattractive to farm labor. And grower success in brcaking their strikes and securing "the arrest aud imprisonment of leading left-wing unionists" contributed largely to the demise. After 1935 the Party adopted the "boring from within" policy working through non-Communist organizations in the field. Ibid. The presence of these people gave growers the opportunity to label the whole union movement, in the field and at the packing houses, as Communist-led and inspired. The growers really knew better. S. Parker Frisselle, President of the Associated Farmers when that organization was formed in 1934, assured the AFL leaders in 1936: "We are in no way in opposition to the American Federation of Labor: We are tremendously interested in the welfare of agriculture, particularly, and we want you to understand that our cards are on the table; that there is no opposition here . . . in any way, shape, or form; and we want your cooperation." Chambers, California Farsc Organizations 62 (1952). But once the AFL entered the picture as an organizer of farm labor, the tune changed. Holmes Bishop, Associated Farmers President in 1939, said of the CIO and the AFL: "The one group was dominated by Communists and the other was led by racketeers ...." Ibid.

111 Asked the extent of labor organization in the orange industry before 1935, Ivan 
of the whole idea of organized labor, one can understand that the witnesses would be very pessimistic about what could be expected if unions were to gain a foothold in agriculture. These expectations, however, were necessarily based largely on an imaginary analysis of the situationnot at all unlike the predictions of crisis and ruin agriculture was sure to suffer if the Mexican Braceros were not allowed into the country. ${ }^{112}$

As miglit be expected, there was an attempt made to persuade Congress that the proposed Logan amendment ${ }^{113}$ did no more than articulate the obvious meaning which should always have been attributed to the agricultural exclusion. Only one of the witnesses, who also objected to the administrative costs that would have to be paid for by the public, doubted the power of Congress under the commerce clause to extend the NLRA to agriculture. ${ }^{114}$ Some effort was devoted to proving that packing

McDaniel answered: "There was no organization of any extent." Hearings on S. 1550, supra note 104, at 3633.

112 S. 1550, 76th Cong., 15t Sess. (1939).

113 "It seems perfectly obvious that it could not have been intended otherwise than that all of these closely related activities should be classed with agricultural labor and that the jurisdiction of the National Labor Relations Act would not apply." Hearings on S. 1550, supra note 104, at 3569 (testimony of Fred Brenckman, Washington representative of the National Grange, speaking for 8,000 granges covering 36 states, 800,000 members).

114 Fred Brenckman, speaking for the National Grange: "It is manifest that under this broad principle of regulating interstate and foreign commerce it is the height of absurdity to pretend that it is necessary or constitutional to go down to the individual farm or the individual farm conmunity to regulate [the] personal relationship existing between farmers and labor employed by them, or local institutions established to carry on the first processing of the products of agriculture." Ibid. "Furthermore, the cost of administration would be tremendously increased through the establishment of unlimited numbers of employees by the National Labor Relations Board." Id. at 3574.

Brenckman's understanding of the National Labor Relations Act was quite inaccurate: "The act had in mind the employment of labor (a) in organizations where considerable numbers were employed, and (b) in substantial centers of population. Furthermore, all discussion indicated that the problem centered around employment by corporate or other organizations where personal relations had largely disappeared." Id. at 3568.

Brenckman was the only representative of agriculture who objected to the inclusion of agricultural labor in the original version of the Wagner Act, which expressly excluded only strike breakers. See note 58 supra. Although he did not appear before the committee, he wrote a letter, apparently because of protests from various parts of the country against the inclusion of farm labor in the Wagner bill. Mentioning these protests in his letter, he wrote: "Uniform labor standards . . . would not be applicable to farm conditions. These conditions vary widely from farm to farm and in different sections of the country .... It is our conviction that the workability of the Wagner bill would be greatly improved if it were aniended so as to exempt farm labor." NLRB, LeGisLative History of the NationaL LABOR Relatrons ACt 1038 (1949). The definition of "eniployee" was amended as Brenckman desired, and as the bill was finally drafted no employers (except of course employers of exempted employees) were excluded. The Committee report (S. REP. No. 573, 74th Cong., 1st Sess. 7 (1935)) stated: "But after deliberation, the conmittee decided not to exclude employees working for very small enployer units. The rights of employees should not be denied because of the size of the plant in which they work." Brenckman apparently did 
operations, because once done on the farm, continued to be purely agricultural. ${ }^{115}$

\section{B. Agriculture's Objections to the National Labor Relations Act}

Two principal lines of thought were developed to supply the reasons for the exclusion of agricultural labor from the NLRA. Promoting an idyllic image of agricultural labor relations, somewhat inappropriate and even ridiculous in view of the number and extent of the labor problems occurring in agriculture during the thirties, ${ }^{110}$ it was first claimed that there was no need for the NLRA in agriculture at all. Second, it was argued that regulation under the NLRA, besides disrupting these allegedly peaceful relationships, would also impose impossible financial burdens on farmers.

\section{Harmony in Agriculture}

The description of rural contentment between employers and employees reached rhetorical peaks. After stating that there are "multitudinous" reasons for keeping agriculture free from labor regulation, ${ }^{117}$ Ivan McDaniel asserted:

A few of them are these, there was no actual labor strife in agricultural operations until this program began operations. Those employees live in small communities, most of them are housewives, they work portions

not follow the bill's history once the exclusion of agricultural labor was guaranteed; he certainly indicated considerable ignorance of its provisions.

115 Reiterating the argument presented to the NLRB in Whittier, that these preparatory processing operations were once done on the farm, Mr. McDaniel was asked by Senator Burke if any farmers "are so far behind the times that they do all those processes theniselves now?" McDaniel's answer destroyed somewhat the thesis that such processing continued to be agricultural in nature: "They can't do then, they can't afford the machinery . . . buildings, so they go together and contribute a certain amount each and build up a plant and get the machinery for all of them. . . . It is an incidental thing, it is like the barn on the ranch." Hearings on S. 1550, supra note 104, at 3631. Some barn 1

116 Jamieson, Labor Unionism in American Agriculture, in U.S. BUREAU OF LABOR Statistics, U.S. DeP'T of LABor, BuLL. No. 836, at 17 (1945), compiled a table of strikes occurring in agriculture throughout the United States from 1930 to 1939. He reports 275 strikes which involved 177,788 strikers and covered 28 states. Some 140 of the strikes, involving 127,176 strikers, occurred in Cahfornia. The vast majority of them took place from 1933 on. (There were only twenty-three from 1930 through 1932.) Considering the financial inability, particularly during those years of depression, to engage in strike activitics which destroy meager earming opportunities, the numbers do not really indicate the extent of dissatisfaction with conditions in agriculture on the part of the work force.

117 The somewhat perverse insistence on describing the National Labor Relations Aet as regulatory of labor rather than protective of labor's rights of free association (which it basically was), clouded the actual effect that exeniption from the act would have. Exemption from the NLRA frees antiunion employers to use any kind of cocrcive tactic-particularly discharge for union activities-to discourage other employees from joining or helping organize a union. This was the kind of "regulation" that agriculture did not want. 
of the year, ... [ [enjoy the same if not better standards of living than city dwellers]. The workers and the farmers are thrown into daily close contact with one another, in many cases they eat at a common table, their children attend the same schools, they bow down together in religious worship; in other words, there is that unity of contact between the farm labor even in these packing houses, and the farmers, that you do not find in industrial centers .... [A]nd this unity which is caused by these natural conditions does more to cement the labor and the employer in those conditions than all of the laws that Congress can ever pass; in other words, they are thrown together by their own natural conditions.

The mechanized theories of industry do not fit in in agriculture, the rigidity of operations does not fit. Agricultural labor is seasonal and widely scattered and closely connected with the family of the farmers. Most of them are daughters or sons or cousins or relatives of the farmers.

The need for collective bargaining does not exist where 1 employer has to deal with only 1 or 2 einployees. . . . Where a few persons are employed on a farm or in a packing shed ... there is very little likelihood of any labor dispute arising which needs collective bargaining as a means of settlement. ${ }^{118}$

This approach was supposed to impress Congress with the idea that agricultural labor, in the packing house as well as in the fields, was so exactly similar to domestic service or employment by parent or spouse that the exemption should be defined to include all employees directly or indirectly involved in agricultural production. ${ }^{110}$

The witnesses appearing before the Senate committee, in attempting to avoid comments that might contradict the declarations of peace and hannony between employers and employees in agriculture, ${ }^{120}$ alleged that any disturbance was only because of radical outside agitators. ${ }^{121}$

118 Hearings on S. 1550, supra note 104, at 3638-39. Several witnesses referred to these "close, personal relationships." Id. at 3568. The image was extremely difficult to maintain. In stark contrast to this picture of sweetness and hight are comments contained in the La Follette Committee final reports. "It is an historical fact that the civil rights of agricultural laborers in that State [California] have never been successfully exercised despite a long record of unrest, misery, and repression. Both the cause and effect of this situation are the completely disadvantaged economic, social, and pohitical status of agricultural laborers." S. REP. No. 1150, 77th Cong., 2d Sess., pt. 3, at 394 (1942).

110 The committee was apparently urged by this approach to consider that these packing operations took place in "local plants usually located in close proximity to the farms," and that they should be grouped with agriculture "because of their generally small size, their actual location as part of the agricultural community . . . Hearings on $S .1550$, supra note 104 , at 3568 .

120 One witness, Chester Moore, a director of the Associated Farmers of Los Angeles County, indicated the unstable nature of farm labor. "Agricultural labor is seasonal, widely scattered, and unskilled. These men drift in and out of this type of work." Id. at 3670.

121 See note 110 supra. 
Outside the context of these hearings-outside of earshot, as it were-a profoundly different attitude was manifested:

Can we expect these new white transient citizens [the dispossessed rural population from the Southern Great Plains, forced out of agriculture by draught and depression] to fill their place? [The "their" refers to the Mexicans who were leaving the State during the depression, characterized as "tractable labor ... impossible of unionizing."]

The white transients are not tractable labor. Being American citizens, they are going to demand the so-called American standards of living. In our own estimation they are going to be the finest pabulum for unionization by either group-the American Federation of Labor or the subversive elements.

We on the land have always recognized that Califorma agricultural labor requirements made impossible to those people so employed the full efforts of American citizenship and the possibility of partaking of our normal standards of life. ${ }^{122}$

Besides being a candid confession that living conditions were substandard, these statements reflect a very harsh unconcern for the Mexican-Americans who were being replaced-a tractable labor force that could be counted on to put up with the situation without succumbing to the appeals of labor organizers. The attempt to blame radical agitators for the labor strife in agriculture becomes unconvincing in the extreme when considered in conjunction with the above declarations.

\section{Hardship to the Farmer}

More convincing and more easily supported were the very strong assertions, emphasized by all the witnesses, that coverage under the NLRA would impose unbearable hardship on farmers. This theory bears careful scrutiny, not only because it is still being repeated today, but especially because the arguments supporting it are crucial to any attempt to justify the exclusion of agriculture from national or state labor legis-

122 These statements originated with Dr. George P. Clements while he was the manager of the agricultural department of the Los Angeles Chamber of Commerce. Hearings Before a Subcommittee of the Senate Committee on Education and Labor Pursuant to S. RES. No. 266 (74th Cong.) to Investigate Violations of Free Speech and Assembly and the Right of Labor to Organize and Bargain Collectively, 76th Cong., 3d Sess. pt. 53, at 19467-68, 19692 (1940) (the La Follette Committee); ChaMrers, op. cit. supra note 110, at 61 reproduces a cartoon of the Associated Farmers, with the title "Possible Effects of Rural Labor Organization," which pictures two hogs picketing the front door of a small farm house with signs reading "we demand better living conditions." Better than a thousand words could, the cartoon indicates a certain insensitivity to the dignity of these workers. This contradicts agriculture's argument that the natural conditions to be found in agriculture were supposed to have developed between the worker and the farmer "a unity of interest which is not found in industry [and which is] .. more effective to remove labor disturbances than any law can be." 84 Cong. Rec. 1806 (1939) (from Senator Logan's statement). 
lation. ${ }^{123}$ The perishable nature of agricultural commodities, the consequent need for uninterrupted harvesting and preparation for market, in addition to lack of control over weather, production, prices, and market provided the material out of which the hardship theory was fashioned. It was put forward to demonstrate the alleged inherent unsuitability of agriculture for labor legislation. ${ }^{124}$

One of two obstacles to dealing with organized labor was, and is, the problem of perishability:

Sen. Ellender: "You do not believe in unionization?"

Mr. Sheppard: "I believe in unionization in a limited way."

Sen. Ellender: "In what limited way?"

Mr. Sheppard: "I would like to point out the very perishable nature of these farm commodities in answering that question. I point out the fact that there is no time for lengthy dispute, for committees to be set up, and arguments to be heard pro and con, and efforts made to settle these propositions when you are dealing with the vegetables that we are growing."

"There is just no chance to carry on the operation and dicker with union labor the way people seem to have to work with union labor."

"Because it is a perishable farm product and has not yet been preserved so that it will keep while the various activities of Labor Boards, and so forth, are set up ... and further because every contract that the farmer might have for the delivery of his crop to one of these plants is so written that if a strike is called the packer is not obliged to take the crop . . . and the farmer is the one who suffers the loss."125

Whether referring to strikes in packing plants or on the farm, it is clear that the real concern was over the impact such a labor dispute would have on the farmer, not the plant operator: "If the tomatoes are in the field it is just the farmer's loss and not the packer's; he can have a strike that can last through the entire packing season, but it is the farmer that stands the loss." ${ }^{126}$ It is not certain that all of the witnesses

123 For the argument today, see text accompanying notes 146-56 infra.

124 In spite of the fact that "Congressional consideration of the agricultural exemption [see text accompanying notes 55-75 supra] was too limited to permit any definitive statement on legislative intent," spokesmen for agricultural interests had no hesitation in imputing to Congress "a belief that the peculiarities of agricultural production render unions undesirable and collective bargaining impossible." Ross, supra note 84, at 135-36.

125 Hearings on S. 1550, supra note 104, at 3580, 3581, 3582 (testimony of Howard Sheppard, vegetable producer and representative of the New Jersey Farm Bureau). The last paragraph was part of an affirmative answer to Senator Ellender's question asking if processors like Heinz Company would be exempted under the Logan amendment.

126 Id. at 3582. The concern was clearly for the farmer, not the packer. Asked about the beer industry, which uses agricultural products, hops and malt, Hugh Hall of the American Farm Bureau Federation, explained why they were not anxious about this industry. "But the manufacture of beer, Senator [Elbert Thomas, the Committee Chairman 
made this same distinction between the possible impact a strike would have on packers, on the one hand, and on farmers on the other. They were in unamimous agreement, however, that any interruption during the harvest season would result in irreparable injury to the farmer:

These commodities are of such a highly perishable nature that time is of the essence, and these farmers have their efforts all tied up in their fields, and when trouble comes, strikes come, and propositions are advanced by the labor groups which are impossible to meet, absolutely impossible, and then the farmer is lost and has no place to go. His stuff must move. That is why agriculture should be exempted. ${ }^{127}$

This unique vulnerability to organized labor's strike action was closely related to a second leading argument concerning imcreased labor costs. It was assunied as axiomatic that any increase in this direction, especially if initiated to settle or avoid the harvest season strike, would necessarily be borne by farmers and not the consuming public. "The result of this legislation has been to pile new and burdensome costs upon farming, costs which because of the inherent nature of farm production, cannot be passed on to the consumers."128 The primcipal reason for this alleged inability to absorb increased labor costs was said to stem from the farmer's lack of control over marketing, distribution, and pricing of farm products. "Agriculture is subject to the vagaries of Nature and has no effective control over the price of its products."120

who was sceptical about the perishability argument and thought it applied to other industries as well], is not one which, if interfered with, would reflect back upon the farmer immediately, and cause the destruction of him and his crop." Id. at 3619.

127 Id. at 3671. (testimony of Chester Moore). McDaniel testified that "even a brief interruption in the movement of certain seasonal perishable farm products to the market may mean loss of the farmer's entire income for a year from that crop." Id. at 3622-23.

$128 \mathrm{Id}$. at 3622 . See also id. at $3568,3574,361 \%, 3653$. Only Mr. Brenckman, of the National Grange, admitted that the added costs might be passed on to the ultimate consumer. However, even here farmers would be indirectly affected, since they are consumers themselves. "[It] is perfectly clear that such regulations [under NLRA] will . . . result in further decreasing hours of labor and efficiency on the one hand and increase wages and cost on the other; all of which must necessarily result in either further lowering prices which farmers will receive for their products (i.c., the processing plants would pass their added labor costs back to the agricultural producers in the form of lower prices) or, on the other hand, increasing prices which consumers, including farmers, will pay for the fimished products." Id. at 3574 .

This objection to added costs which supposedly could not be passed on was the principal objection of agricultural interests to the minimum vage and maximum hours provisions of the FLSA. Exclusion oi agricultural labor under the latter act was taken for granted from the beginning; the real issue concerned the scope of the exemption. Besides arguing that such wage and hour legislation would raise the cost of manufactured goods and entice farm labor into the cities, it was claimed that coverage of the food preparation industry would mean higher costs in food processing which would reduce farm income. See Ross, supra note 84 , at 173-75. This approach to labor-costs underlay agriculture's negative reaction to the NIRA. See note 46 supra.

129 Hearings on S. 1550 , supra note 104, at 3639. Even producers of non-perishable 


\section{Further Objections}

Supplementary arguments for expanding the definition of agricultural labor beyond the meaning attributed to that term by the Labor Board were not wanting. The nation had to be protected from the machinations of radical union leaders, attempting to gain control of the country's food supplies through domination of the farmers' labor force. It was asserted that the Board, and its agents, were assisting in this nefarious plot. ${ }^{130}$

Less dramatically, but no less emphatically, the NLRB was charged with creating chaos im the food packing industry, ${ }^{131}$ and of destroying the morale of its employees. ${ }^{132}$ Other complaints were made concerning the Board's procedural set-up, ${ }^{133}$ and its supposed bias against growers as manifested in its prejudgment as to what was and was not agricultural labor. ${ }^{134}$ Admimstrative difficulties in determining fairly and accurately whether or not unfair labor practices were occurring were suggested. ${ }^{135}$

items were assumed to be unable to cope with increased grading costs: "[I]f anything is done that tends to increase the cost of grading beans . . . every penny of it comes out of the farmer who brought in the beans." Hearings on S. 1550, supra note 104, at 3617.

130 "The issue is . . . whether the United States Government through the National Labor Relations Board and its agents, as is now being done, should assist any organization in its efforts to dominate the farmers' labor and gain control of the sources of the food supply of the Nation . . . "Id. at 3622. "The control of the labor involved in those packing house operations through which farm products pass . . . will result in the control of the Nation's food supplies as these establishments are the bottle necks through which these products must flow." Id. at 3623. Senator Logan's statement is an almost identical comment. 84 CoNG. REC. 1804 (1939). There can be no doubt but that the intention was to implicate the Communists in this attempt to gain control of the nation's food supply. Id. at 1806.

131 It allegedly used the NLRA "to create chaos and unrest in farmer-owned fruitpacking plants ...." Hearings on S. 1550, supra note 104, at 3622. "No valid labor strife now exists in the agricultural field except when stirred up by outside organizers and experience has shown that such strife is likely to arise if certain labor organizers, supported by the agencies of the National Labor Relations Board, set out to gain control of agricultural labor and agricultural production." Id. at 3639.

132 Id. at 3575. The arguments were all intermingled: "The failure of the National Labor Relations Board to recognize the exemption of agricultural labor imposes a severe lardship upon agriculture. The situation complained of increases the farmer's marketing costs and destroys the morale of those employed in the packing plants. It likewise interferes with the speedy movement of perishable products, the value of which is lessened or destroyed unless they are moved promptly." Id. at 3575 .

${ }^{133}$ Besides complaining that the Board exercised the ordinarily separate functions of examiner, prosecutor, and judge - which is common to all administrative agencies-it was charged with abusing its powers to "persuade workers to join an organization," or of "setting out with the idea of finding the respondent employer guilty [of unfair labor practices], if possible." Id. at $3608,3630,3632$.

134 Much was made of the fact that a Board memorandum issued before any hearings on the agricultural issue had recommended that the definition of agricultural labor should be limited to "cultivation and tillage of the soil and feeding and care of livestock." Id. at 3624 .

135 "In the handling of these perishable crops, variation in weather conditions requires quick and extensive changes in methods and plans, which may create opportunity for 
And a rather fantastic attempt was made to prove that equality of bargaining power actually existed between employers and employees in agriculture. ${ }^{136}$

Finally, it was argued that the Board's action "usurping jurisdiction over various cases in which agricultural labor is involved, ... has in effect nullified the exemption granted by Congress."1137 Even allowing for the ordinary exaggeration accompanying appeals for legislation, this is an unusual statement. It serves to underscore most emphatically the importance attached to broadening the definition of agricultural labor by these witnesses appearing for agriculture. Indeed, taking the statement at face value, the very existence of agriculture was made to depend upon obtaining the Logan amendment. If it were not obtained, agriculture would be within the control and subject to the domination of organized labor. Moreover, farmers, already receiving depressed prices for their products, would be forced to accept even less since packing plants would necessarily pay less to absorb the inevitable increased labor costs. If the packing plants refused to agree to the demands of their organized workers, then farmers would lose all. A grim picture-and logically plausible if one assumes that the reasoning of agriculturahsts was founded on established and unassailable facts.

\section{$\mathrm{V}$}

OID ARGUMENTS NEVER DIE

Experience has demonstrated overwhelmingly that agriculture's exceedingly pessimistic appraisal of organized labor's aims and capabilities has never approximated the actual facts. Congress refused to enact the Logan bill, leaving the exclusion of agricultural labor as originally written, as it has remained to this day. ${ }^{138}$ Processing workers, both in com-

persons so inclined to contend that such charges [changes?] constitute unfair labor practices." Id. at 3630. Linked to charges of bias on the part of the Board, such contentions pose a more serious problem than administrative conplexities.

136 Id. at 3638. The statement was based on an analysis of xural population: 33 million persons living on 6 million farms; 10.5 million wage earners; for each wage earner there were, therefore, three persons contributing capital and labor ( 5.5 persons per farm; 1.75 wage earners per farm). This approach only obscures the reality. In 1954 , only 82,022 of $123,075(66.6 \%)$ farms in Califorma employed hired labor. Of these farms, no more than $6,628(5.4 \%)$ employed 183,628 hired laborers, $66.1 \%$ of the total hired labor force, or 27 men for each of these farms. Dividing the total number of laborers $(277,753)$ by the number of farms $(123,075)$ gives the misleading figure of 2.2 hired laborers per farm. Sce

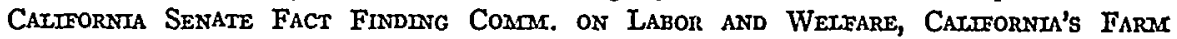
Labor Probleans pt. 1, at. 52, figure 39 (1961).

137 Hearings on $S .1550$, supra note 104 , at 3574 .

138 The bill died in committee. "No witnesses appeared in the interest of workers whose exclusion was demanded." Ross, Agricultural Labor and Social Legislation 241 (1941) (unpublished thesis in the University of California at Berkeley Library). The 
House established a special committee pursuant to H.R. 258, 76th Cong., 3rd Sess. (1939) to "investigate alleged malpractices of the N.L.R.B." (This committee was popularly known as the Smith Committee after its chairman, Howard Smith of Virginia.) The record consists of twenty volumes of hearing reports. While nothing was said about the Board's interpretation of agricultural labor, the committee report declared: "As shown in the body of the report, the Board has attempted to extend its jurisdiction to fields specifically denied it by the Congress." See H.R. REP. No. 1902, 76th Cong., 3d Sess. pt. 1, at 87 (1940). The report recommended saving farners "from predatory encroachment by the Board." Ibid.

Agriculture's next opportunity developed while the Taft-Hartley amendments to the NLRA were being considered. The Taft bill (S. 1126, 80th Cong., 1st Sess. (1947)) would have added to $\S 2$ which defines "employee" a new subsection (13) defining agriculture in the exact terms found in $\S 3(f)$ of the Fair Labor Standards Act. See text accompanying note 87 supra. The Hartley bill (H.R. 3020, 80th Cong., 1st Sess. (1947)) would have adopted the much broader language of the Social Security Act as amended in 1939:

The term "agricultural labor" includes all services performed-

(1) On a farm, in the enploy of any person, in connection with cultivating the soil, or in connection with raising or harvesting any agricultural or horticultural commodity, including the raising, shearing, feeding, caring for, training, and management of livestock, bees, poultry, and fur-bearing animals and wildlife.

(2) In the employ of the owner, or tenant or other operator of a farm, in connection with the operation, management, conservation, improvement, or maintenance of such farm and its tools and equipment, or in salvaging timber or clearing land of brush and other debris left by a hurricane, if the major part of such service is perforned on a farm.

(3) In connection with the production or harvesting of maple syrup or maple sugar or any commodity defined as an agricultural commodity in section $15(\mathrm{~g})$ of the Agricultural Marketing Act, as Amended, or in connection with the raising or harvesting of mushrooms, or in connection with the hatching of poultry, or in connection with the ginning of cotton, or in connection with the operation or maintenance of ditches, canals, reservoirs, or waterways used exclusively for supplying and storing water for farming purposes.

(4) In handling, planting, drying, packing, packaging, processing, freezing, gradimg, storing, or delivery to storage or to market or to carrier for transportation to market, any agricultural or horticultural commodity, but only if such service is performed as an incident to ordinary farming operations or, in the case of fruits and vegetables, as an incident to the preparation of such fruits or vegetables for market. The provisions of this paragraph shall not be deemed to be applicable with respect to service performed in connection with commercial canning or consmercial freezing or in connection with any agricultural or horticultural comnodity after its delivery to a terminal market for distribution for consumption.

As used in the subsection, the term "farm" includes stock, dairy, poultry, fruit, fur-bearing aninal, and truck farms, plantations, ranches, nurseries, ranges, greenhouses or other similar structures used primarily for the raising of agricultural or horticultural commodities, and orchards.

53 Stat. 1377-78 (1938), as amended, 42 U.S.C. $\$ 410(f)$ (1964).

Commenting on this proposed amendment, the minority of the Committee on Education and Labor declared that it had not been put forward in "the interest of fanners but of the operators of industrial and commercial processing plants. The National Labor Relations Board has carefully observed the distinction between commercial operations and farming operations and no good reason appears for extending the exemption to persons who are actually engaged in industrial operations." H.R. REP. No. 245, 80tb Cong., 1st Sess. 360 (1947). The majority made no comment at all on the proposed change. The 
mercial canneries and rural packing sheds, have been substantially and effectively organized. ${ }^{139}$ But labor's control of agriculture has failed to materialize; indeed, the very prediction seems to have been motivated by something akin to hysteria. Admittedly, costs have risen in processing as everywhere else, but while prices received by farmers for their products have failed in many cases to keep pace with these increases, ${ }^{140}$ the consuming public has more than borne its share. And the strike weapon in the food processing industry has not been used to force farmers to their knees or cause them sigmificant crop losses.

Even though no one appeared to argue the case for the workers whose

Senate minority of the Committee on Labor and Public Welfare repeated almost verbatim the above comment. S. REP. No. 105, pt. 2, 80th Cong., 1st Sess. 39 (1947).

Senator Smith of New Jersey explained the Senate amendment as follows: "But generally speaking the agricultural workers of the Nation, certainly in my State, do not want the principles of union labor applied to the farms. I am very sympathetic with them, because the situation on the farm is so different from what it is in the factory. On the farm the bours of labor which prevail in industry cannot be observed." 93 Cong. REc. 4283 (1947).

Subsequently, both House and Senate amendments were dropped in conference. Senator Taft merely mentioned the decision without explaining it. 93 Covo. Rec. 6441 (1947). The House conference report, however, gives an indication of what happened. "Since the matter of the 'agricultural' exemption has for the past 2 years been dealt with in the Appropriation Act for the National Labor Relations Board, the conference agreement does not disturb existing law in this respect." H.R. CoNF. REr. No. 510, 80th Cong., 1st Sess. 33 (1947).

Beginning in 1946 (fiscal year 1945-46) Congress has limited, without amending the National Labor Relations Act, the Board's jurisdietion: "No part of the appropriation shall be available to organize or assist in organizing agricultural laborers or used in connection with investigations, hearings, directives, or orders concerming bargaiming units composed of agricultural laborers as referred to in section 2(3) of the Act of July 5, 1935 (29 U.S.C. $\S 152$ (N.L.R.A.)), and as amended by the Labor-Management Relations Act, 1947, as amended, and as defined in section 3(f) of the Act of June 25, 1938 (29 U.S.C. $\S 203$ (F.L.S.A.)) . . ." 79 Stat. 609 (1965). See text accompanying notes 86-88 supra for the definition of agricultural labor as contained in the Fair Labor Standards Act.

The House conferees, unable to persuade adoption of their broader definition, agreed to the Senate amendment. Since the Appropriations Act already applied, in effect, the limitations of the Senate amendment (copied from $\S 3(\mathrm{f})$ ), no one felt the need to amend the law. The appropriations rider has been continued annually. It is construed narrowly, excluding only operations conducted on the farm. It does continue the artificial classifications begun with the NIRA. See text accompanying notes 38-47 supra.

139 Fuller, Labor Rejations in Agrtculture 10 (1955).

140 The higher cost of labor in processing agricultural products, definitely a result of union achievement, is only one item, and not the major one, of the many factors resulting in the "cost-price squeeze" that has been plaguing agriculture for years. The increasing use of "nonfarm produced items [capital outlays for equipment, machines, etc.] in the production of crops .... are a major contributing factor in the 'cost-price squeeze." Caltrornta Senate fact Finding Comm. on Labor and Welfare, Cattrornia's Farm Labor Probiems pt. I, at 34 (1961). (Emphasis added.) Increased production, with its exceeding of demand, has also had its part to play in creating a downward pressure on farm prices. $I d$. at 38 . 
exclusion was being demanded, Congress, unimpressed by all the uproar, refused to impede union efforts to organize the food processing industry by exempting its workers from the protection of the National Labor Relations Act. The progress of organization in that industry has amply demonstrated that agriculture's fears of the labor movement were largely irrational. ${ }^{141}$ Furthermore, the failure to obtain a broadened definition of agricultural labor has by no means rendered the original exemption useless, as was so vehemently claimed. With the industrialized packingpreparation-processing operation substantially organized, the campaign to get it excluded and the arguments supporting that effort have been abandoned. While these arguments would sound ridiculous today, at least in relation to an industry so closely allied to agriculture, they have not been discarded with respect to the farm laborer strictly defined. ${ }^{142}$

\section{A. Congressional Interest and Concern Mount}

The arguments of agriculture were given maximum exposure before the Senate Subcommittee on Migratory Labor, ${ }^{143}$ during 1965 and 1966. The Subcommittee was holding hearings on five bills pertaining to agricultural labor, ${ }^{144}$ one of which would end the exclusion from labor legis-

141 Denying any validity to the labor movement among their workers, concentrating all their energies towards defeating organized labor and strike-breaking, discharging employees for umion activities, deputizing their neighbors, and arresting and harassing pickets and union leaders, these men could not begin to conceive of mature labor relations. Their judgment as to the results of umonization among farmworkers was necessarily colored by their own experience and that of their associates. Lacking any familiarity with anything approaching the procedures of collective bargaining, they could not possibly have any basis other than imagination for their position.

142 In 1961 a Califorma Senate committee found that agriculture's principal objections against legal protection of their workers' right to self-organization were: "(1) The extreme vulnerability of the farmer to strikes because of the perisbability of most farm products; (2) The mability of the farmer to control the price he receives for his produce; (3) The economic inability of the farmer to increase wage rates, the only major cost factor primarily within his unilateral control; and (4) The farmer believes he is 'engaged in society's most useful and necessary enterprise, and [is] entitled to the special considerations which the dignity of his occupation commands. He regards himself as a natural agent of the forces of freedom .... He believes that he has a riglit as a farmer to an adequate supply of labor. Trade unions be regards as threats to the exercise of his basic rights." CaIIFornda SENate Fact Findnig Conar. on Labor and Werfare, Caiffornia Farm Labor Problems pt. 1, 202 (1961).

143 This committee is a subcommittee of the Senate Committee on Labor and Public Welfare. Senator Harrison Williams (New Jersey), is the chairman; Senators Robert Kennedy (New York), Edward Kennedy (Massachusetts), Gaylord Nelson (Wisconsin), George Murphy (California), and Winston Prouty (Vermont) compose the subcommittee.

144 These hearings took place on July 7,8 , and 13, 1965, at Washington, D.C.; on March 14, 15, and 16, 1966, at Sacramento, Visalia, and Delano, California; and on April 12, 1966, at San Antonio, Texas. The bills, introduced into the Senate on April 30, 1965 are: S. 1864, to provide minimum wage regulation for farmworkers; S. 1865, to eliminate child labor from agriculture; S. 1866, to amend the NI.R.A., to make its provisions applicable to 
lation. The arguments were exactly the same as those first presented to Congress in 1939 to justify, and, indeed, to demonstrate an absolute necessity, to exclude processing workers from the NLRA. Although the faces have changed and the objective has narrowed down to preserving the original exclusion, most of the old farm organizations were present to carry on the battle. ${ }^{145}$

Matt Triggs of the American Farm Bureau Federation was the leadoff witness in opposition to the bill which would amend the labor act to end the thirty-year-old exclusion:

Conditions in agriculture are so different, as compared with the conditions in industry, that no union should be empowered to act as the exclusive bargaining agent of the workers employed by farmers.

The unique feature of the employment relationship in agriculture is the vulnerability of the farmer to any work stoppage on his farm.

While most industrial or commercial concerns may suffer a reduction in profits as a result of a strike, it is rare for them to be disastrously affected. For the most part they can close down their operations and sit out the strike with nominal losses.

Compare this with agriculture. It is not possible to close down a farm. Operations must continue in tune with the season. Crops must be harvested when ready. Even a delay of a few days may substantially reduce the value of a crop.

If a strike should occur when a perishable crop such as fruits or vegetables is ready to harvest, and of course this is the time a strike would be called, this would entail much more than a reduction in the farmer's profits for the year.

More likely it would involve, one, a loss of income for the year and, two, a loss of money invested in bringing the crop to harvest stage which may run, for many fruits and vegetables, $\$ 300$ or $\$ 400$ an acre or more. A loss of this size would bankrupt many farmers.

Thus the farmer is in no position to stand a work stoppage. Come what may he must get his crops harvested. He must therefore accede to almost any demand upon him at harvest time which is necessary to prevent a work stoppage no matter how unreasonable or arbitrary the demand may be.

Collective bargaining would not equalize the bargaining power of farmers and workers; it would make farmers subservient to labor union leaders wherever such leaders could establish the practice of collective

farmworkers; S. 1867, to provide an improved recruiting and transportation system for farmworkers; and S. 1868, to establish a National Advisory Council on Migratory Labor. 89th Cong., 1st Sess. (1965). See Hearings on S. 1864, S. 1865, S. 1866, S. 1867, and S. 1868 Before the Senate Subcommittee on Migratory Labor of the Senate Committee on Labor and Public Welfare, 89th Cong., 1st \& 2d Sess. 2, 5-33b (1965-1966).

145 The National Farmers Union, represented by Blue Carstenson, and the Cahifornia Farmer-Consumer Information Conmittee, both supported all five of the Williams bills. The former association is comprised of some quarter of a million farm families, with most of its strength lying in the Northern Midwest. See Hearings on S. 1866, supra note 144, at 152, $156,159$. 
bargaining.

Because of this extreme vulnerability of farmers we reaffirm our position that collective bargaining should not be applicable to farmer employers. ${ }^{146}$

The most prominent argument offered, which emphasized the farmer's inability because of the perishability of his crops to negotiate with organized labor placed the rest of agriculture's position somewhat in the shadow. ${ }^{147}$ The difficulty of absorbing added labor costs and the impossibility of passing them on to consumers were not, however, forgotten:

The farmer's work for the entire year may be tied up in this crop. $\mathrm{He}$ is in no position to bargain at that time because a strike or other coercive activity could destroy his entire year's efforts.

Except in cases of acute shortages, the farmer is not in a position to pass on added costs to the consumer. He must take what the market will pay for his product in competition with other agricultural products produced in his own area, as well as im other States or in foreign countries. His wage structure must be held within the limits of the funds he receives from his products and cost of operations. Otherwise it is impossible for the farmer to stay in business and offer jobs to workers. ${ }^{148}$

Finally, organized labor's power was added to the argument. "Looking to the purposes of the bill, this would give to the unions a monopoly over agricultural labor, so that the unions could effectively control the food supply of the Nation through control of the labor which produces this supply. This, in our opinion, is against public policy."148

Subordinate arguments were not neglected: Administrative difficulties were again suggested; ${ }^{150}$ agricultural production was alleged to be beyond the reach of the Constitution's commerce clause; ${ }^{151}$ and it was claimed

140 Hearings on S. 1866, supra note 144, at 95-96. See also id. at 110 ("ruinous to agriculture"); id. at 114 ("would burden the producer or grower . . . with costs he cannot afford to assume . ... perishable commodities . . . must be handled . . . when . . ready"); $i d$. at 116 ("overriding question is the question of strike at harvest"), id. at 124 ("Congress in its wisdom has excluded agriculture . . . because of the extreme vulnerability of the grower."). See also id. at 135, 145, 233, 244, 250, 252, 337, 343, 418, 725, and 791.

147 "It can only be blackmail when coupled with the threat of crop loss." Id. at 117.

$148 I d$. at 337 . See also $i d$. at $96,139,145,249,342,725,740$.

148 Id. at 336. "Statutory collective bargaining could mean the strangulation of our food supply by a relatively few persons." Id. at 418. "Many years ago, Congress in its wisdom, realizing that the uninterrupted production of food is the most important single activity performed by man for man, exempted agriculture from the labor laws. This was not for the purpose of singling the farmer out as a preferred citizen but rather to insure that no part of our society would be able to gain control over an industry that the people are so dependent upon. We all know what would happen if this occurred as we have had many examples of the lengths men will go to gain control over their fellow man." Id. at 358.

$150 \mathrm{Id}$. at 342.

151 "It has been the accepted legal concept that production of goods for commerce reaches only the handling of the product after harvest and does not reach the production, harvesting on the farm, and transportation of the product from the farm to the establish- 
that such legislation would increase unemployment, and injure the very people it was supposed to help. ${ }^{152}$ Labor legislation, it was further argued, would drive farmers out of business, ${ }^{153}$ and increase the movement of agriculture to areas outside the United States, especially Mexico. ${ }^{154}$

ment where it is prepared for market." Id. at 336. This view is hard to understand in light of the Supreme Court's decision in Wickard v. Filburn, 317 U.S. 111 (1942), which held that Congress had authority under the commerce clause to regulate even the production of wheat consumed entirely at the farm on which it was grown on the theory that changes in the volume of such wheat could affect supply and clemand for grain sold across state boundaries.

162 Hearings on S. 1866, supra note 144, at 108. The argument again was made chiefly in relation to the minimum wage proposals.

153 Both this and the increased unemployment in agriculture arguments are belied by the figures regarding the decreasing number of farms in the United States and the reduced work force in agriculture. Between 1940 and 1960 the number of farms has dropped from 6.4 million to 3.5 million. Farms with more than 500 acres ( $9 \%$ of all farms) accounted for $61 \%$ of farm land in 1959; farms with more than 200 acres (22\% of all farms) had $76 \%$ of the farm land. While the number of farms continues to decline, the average size continues to rise. Id. at 6 . It would be hard to drive farmers out of farming faster than present economic conditions have been doing for years.

The same thing is true of the work force employed in agriculture. There were $3,190,000$ agricultural workers in 1930, while by 1964 the figure (annual average farm labor employment) lad been reduced to $1,604,000$. Increased productivity has a good deal more to do with the lower number of farm workers than the raising of wages does. Id. at 86 .

154 Again, analysis of the data available indicates that this trend, begun while the Bracero law was in full swing, will continue in any event. U.S. imports fronı Mexico (fresh fruits and vegetables) from 1954-1965:

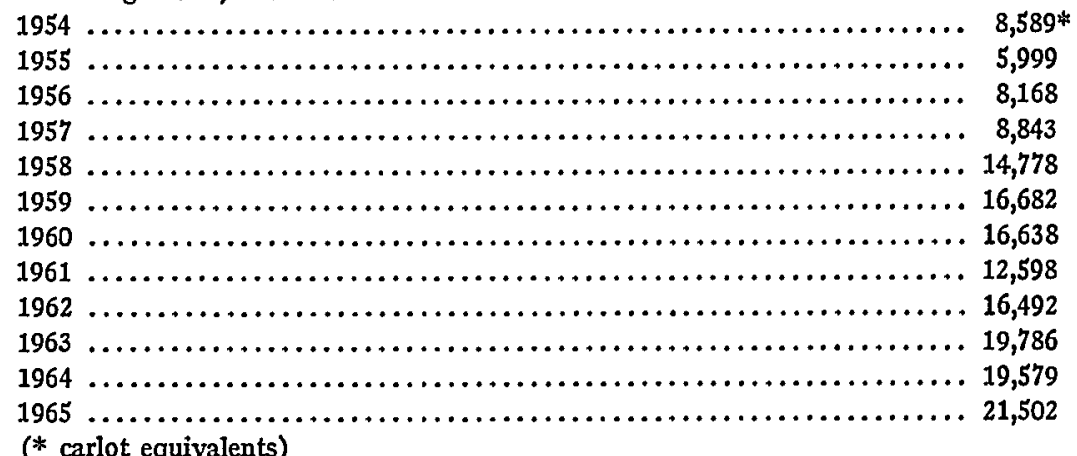

Id. at 339. This indicates that the whole of the imports from Mexico in 1965 was a little less than the quantity of apricots produced in California in 1959-which equaled $.8 \%$ of California's farm production. Asked about the alleged threat of Mexican competition, Othal Brand, president of a Texas produce, process, export and import firm, answered: "[W]e lave a substantial tariff structure of long standing .... and the distance, the freight factors, and all that, are part of the costs before a commodity reaches the U.S. side of the border-are so prohibitive that when our own commodities are in production, generally, we are unable to import from any country. ... I think it's a whipping boy that's often used; people look for something to blame their problems on. But, as far as the imports, the smali percentage of the gross consumption that is involved in the imports from Mexico, and other countries, and the fact that they are, in the main, out of season items that are not available in the United State, I don't think there's any real relation in most commodities, to-between the two." Id. at 800 . 
Finally, it was contended that the states should be allowed to regulate the problem, ${ }^{165}$ and that much more study was required before Congress should act. ${ }^{156}$

Agaim, the purpose and aim of the NLRA seems to have been misunderstood. It was suggested during the Senate hearings that since farmers can join cooperative marketing associations on a voluntary basis, the workers should also be left free to do so.

Farmers who belong to farmer cooperatives do so voluntarily. There is no organization from the "top down" in a farmer cooperative, which we believe possible for covered industries under the National Labor Relations Act. Farmer cooperatives are owned and controlled by farmer members. They join or withdraw on a voluntary basis, depending on the economic benefit they derive and their belief in the type of operation.

We question whether we would want such an arrangement among farmers and their cooperatives as organized labor wants for farmworkers-the mandatory requirement of belonging to an organization ....

[While we believe labor organizations should receive the same encouragement from government that farmers do in forming their cooperatives] we question the "protection" of agricultural laborers when recent history has shown the inability of labor unions to organize farmworkers on a voluntary basis .... The lack of success ... indicates that the workers themselves are not overwhelmingly enthusiastic about organizing into a union. ${ }^{167}$

$155 \mathrm{Id}$. at 336.

156 "[A] thorough study should be made of the economic factors involved in each crop in each area of each State." Id. at 337. If this approach were adopted there would be no legislation for years. See also id. at 131.

157 Id. at 144. The argument, made by Richard O'Connell of the National Council of Farmer Cooperatives, was based on an analysis of one section in the proposed bill which would amend $\$ 8(f)$ of the NLRA (National Labor Relations Act, $\$ 8(f)$, as amended, 73 Stat. 545 (1959), 29 U.S.C. \& 158(f) (1964).) Section 8(f) allows the construction industry, because of its umique employment and job situation, certain labor practices that would ordinarily be prohibited. Since all the terms of employment must be arranged before any job is commenced, the section permits "pre-hire" contracts between employers and unions in this industry, even though the majority status of the union may not have been established by an election. It would paralyze collective bargaining to force contractors and unions to wait until after the job had begun, the work force hired, and an election held to determine whether or not the unions involved actually represented the workers. This presents no problems where the work force is highly organized, as it is in construction, for there are generally no questions at all about representation. The section further allows the contract to require, as a condition of employment, that the workers join the union within seven days of employment. The contract can also require the employer to give the union an opportunity to refer qualified applicants for job openings, and can specify training or experience qualifications for applicants.

This kind of provision undoubtedly gives the umion a very strong control over the work force-but only where the work force has already been effectively organized. Nothing in the law requires such contracts. If the employer really doubts that the unions actually represent the men he is going to hire, he can refuse to deal with them. And if the work 
The nature of the work force engaged in agriculture was described candidly. There were no more references to farmers and workers living in close contact, eating at common tables, and bowing down together in worship..$^{158}$ Instead the haphazard character of the farm work force, particularly in seasonal labor, was underscored. "Farmers do not deal with a stable year-round labor force; more specifically they deal with a day-to-day, month-to-month labor force consisting of different individuals. There is no identifiable labor force for agriculture."160

In sharp contrast to earlier hearmgs when agricultural interests held the stage alone without fear of contradiction or rebuttal, the Migratory Labor Subcommittee heard considerable testimony from organized labor, church leaders, and others in favor of extending collective bargaining to farm workers. No one, however, really answered the principal objections of agriculture to labor legislation, not even the representatives of the

force has not been organized, such refusal to bargain will not hurt him in the least. Where organization has occurred, and the contending unions have, in fact, signed up the majority of the workers, it would be ridiculous not to deal with them. There is, however, nothing in $\S 8(\mathrm{f})$ that makes this prior organization of the work force mandatory, nor is there anything in the section that requires contracts calling for obligatory union membership within any period.

In agriculture, where unions are virtually non-existent, and where there is very little established membership, and the few members there are do not have the resources to support the union's use of strike action, $\S 8(f)$ would be practically useless; indeed, it nuight be an obstacle. Farmers could sign "pre-hire" agreements with sham organizations, for example, the labor contractors with whom they have long dealt. While that would be an unfair labor practice, the Board's procedures are slow and the season would be over before sucl a case could be decided. By that time there could be a substitute "paper" union with which the farmer could deal. The only effective way to deal with this latter kind of situation would be the strike-which is to say that only an already substantially organized work force could prevent farmers from controlling their lahor in this way. Any way you look at it, national labor legislation is not a mandatory procedure to effect the organization of the work force. Once organization has occurred the law does provide umions with the means of protecting and even furthering their majority status. However, none of these techniques provided-union shop, hiring hall, apprentice programs, and so forth-can be maintained unless supported by the membership.

Again, even though the employer may have made an agreement with the union under $\S 8(f)$, he may still petition the Board for an election to test the union's majority status. The workers can do the same. They can also petition for de-authorization of the unlon's authority to make an agreement requiring union membership.

158 See text acconpanying note 118 supra. "Because of the temporary character of such employment [at harvesttime], farmers ordinarily employ virtually anyone who is available ... the able bodied and the infirm, the ambitious and the shiftless; the young, middle aged and elderly; the mentally alert and those who are mentally or psychiatrically handicapped .... [H]e must employ those who are available, and accept the qualifications, or lack thereof, they bring to the job." Hearings on $S$. 1866, supra note 144, at 89-90 (testimony of Matt Triggs). While it was asserted that minimum wage legislation would destroy "this pattern of enployment," id. at 90 , it is equally true that collective bargaining would end it also, which would be a small loss.

159 Id. at 332-33 (testimony of Lester Heringer, President, California-Arizona Farn Labor Association). 
packing house workers. The accent was on justice, equality under the law, and on denying that there was any rational basis for the exemption. But the advocates of extension did not provide the subcommittee with an adequate response to the farmers' very real fears of strikes and the possibility of union control of their operations.

For example, Secretary of Labor Willard Wirtz labeled the portrayal of agriculture as different from other kinds of employment as "an old and established myth:"

There may have been sounder reasons in some earlier period for the arguments that agriculture deserves, for some unidentified reason, a Government-guaranteed foreign labor supply, that normal persounel policies don't apply here, that the farm produce market won't support fair wages, that farm employment must be excluded from the coverage of laws regarding employment generally.

If there were once good reasons for these attitudes, they are now covered deep with history's dust. ${ }^{160}$

Declaring that the exemption of farm labor from collective bargaining laws was "an anachromistic carry-over from the period of disproportionate political influence by rural voters," he predicted that "national acceptance of the principle of one-man, one-vote," would end the exclusion. ${ }^{161}$ This all may be true, but it does not indicate wlyy one would conclude that agriculture's position lias been based on myth; instead such an approach only tends to heighten the farmer's worries about organized labor, which appears to him to be backed by a government that does not believe he has any problems.

\section{B. Organized Labor}

Organized labor's representatives were not a great deal more helpful for the agricultural worker's position. Fully prepared to analyze the cost situation with respect to the minimum wage amendment ${ }^{162}$ which would be equally applicable to wage raises gained through collective action, their support of labor legislation was devoid of constructive criticism of agriculture's position:

160 Id. at $38-39$.

161 Id. at 39. The Secretary made it clear that these were his personal views and that no Administration position had been advanced on these issues. He did not, however, "want to imply in any way there is any different view within the administration." Id. at 38.

162 In regards to cost, it was argued that increased labor costs, which would drive up prices of agricultural commodities, would benefit the vast majority of small farmers who do their own work. The return for this labor is measured by current farm wages. Figures from the 1959 census of agriculture indicate that the vast majority of American farms $(2,103,516$ out of $2,416,617$, or $87.1 \%$ ) employed less than one hired laborer per farm. The real impact of higher wages would fall on the top $12.9 \%$ of America's corporate farms which, in 1959, paid $70.7 \%$ of the farm wage bill. Again, output per man-hour has been increasing about twice as fast as farm wages. Id. at 169-70. 
Agricultural workers, unlike other workers, are effectively denied the right to organize. This fact is the major reason for the miserable wages and working conditions under which farmworkers suffer ....

The law of the jungle prevails in agricultural labor relations. Growers band together to prevent organization. They blacklist those growers who sign union contracts. They subsidize those growers who are struck by the union .... .

There is no reason-except the political blackmail exerted by the farm bloc in the past-for the exclusion of agriculture from the Labor-Management Relations Act. We therefore urge the enactment of S. $1866 . .^{163}$

Whether totally accurate or not, this argument is no answer to the farmer who worries about the union which could ruin him in a few days. Asked specifically if he knew "of any other industry that's comparable to farming where a brief strike could destroy the entire year's product,"104 William Kircher, the AFL-CIO Director of Organization, answered: "I can't think of any, and I don't think that's any reason that there aren't any. I don't know."105 The obvious answer-the experience of the food processing mdustry-did not occur to him. He instead net the implication of the question by suggesting there was nothing to worry about:

And I don't think that the dire forebodings of the peculiarities of the product of this industry as against another is really so great when measured in the framework of what our experience lias been with respect to what labor and management can really do once they sit down at the bargaining table and realize that they have a responsibility to each other and a responsibikity to the community..$^{100}$

The research director of the United Packinghouse, Food and Alked Workers Union, which has 125,000 food processing workers among its members, was less assuring. Asked if he thought it was possible that a grower could be driven to the wall in one year because of his vulnerability to the strike, Mr. Napuk answered: "Certainly"167 - a remark hardly confforting to the farmer. The dialogue continued:

$163 I d$. at 172 . The supporters of collective bargaining agreed that political factors were responsible for the exclusion: "arbitrarily excluded" (id. at 211); "they [the exclusions] were written ... simply because the farm bloc in Congress and in the state legislatures appeared all powerful . . . the pound of flesl . . to pass New Deal legislation . . . ." (id. at 402); "[there] has never been any reason, other than the political power of those opposing the rights of agricultural workers to organize, for denying them the protection of the NLRA." (Id. at 463.) Although, admittedly, political power was at work, plausible arguments have been advanced, even if after the exclusion was an establisled fact, that justify this use of political power. It will not be neutralized by merely adverting to it-the poverty of the supporting arguments must be exposed.

104 Id. at 296.

165 Ibid.

166 Id. at 297.

107 Id. at 225 (testimony of Kerry Napuk). 
But Senator (Williams), it just happens in this particular situation, the strike has the greatest leverage. This is the only way it differs from strikes in other industries. The fact is that there would seem to be a greater leverage on the part of workers than on the part of management.

I do not see anything wrong with this. I am not horrified by this situation. Hypothetically speaking, assuming that there is a strike, ... the chances of withholding labor long enough to destroy a crop is very remote, in fact, it has never happened, the reason it has not happened is either there are other workers to replace the strikers or there has been a settlement.

Assuming that the demands of the farmworkers are reasonable, and they usually are, all the grower has to do to avoid the strike is to accept those terms of employment. ${ }^{168}$

This may be true; but suppose the demands are unreasonable, as farmers are convinced they will be, and that the work force is organized sufficiently to keep out the strikebreaker. Then what? If the farmer accepts the unreasonable terms, he loses; if he holds out, he loses even more. It is no answer to declare that "this is the fear-not of losing crops because this is a smokescreen. The real reason is that they might have to give a piece of the pie away."109

\section{An Answer to the Fears of Agriculture}

Indeed, there is no logically complete answer to the farmer's fears of crop loss, impossible labor costs, and domination by union leaders. But there was no logical response to these same fears in 1939 when agriculture tried, unsuccessfully, to rid itself of organized labor in the food processing industry. The only arena in which agriculture's evaluation of organized labor can be validly tested, however, is actual experience. The thirty years' experience of the food processing industry has sufficiently demonstrated the poverty of farmers' thinking about unionism. ${ }^{170}$ In addition to the experience of the food processing industry, agriculture should consider the field workers in Hawaii, who have been organized for twenty years. ${ }^{171}$ There the employers had all the familiar fears, which were heightened considerably by the fact that the organizing group was Harry Bridges'

108 Id. at 226.

$169 \mathrm{Ibid}$.

170 California's Governor Brown noted the analogy of agriculture to the processing industry in his statement to the Williams Committee: "There will be arguments presented against giving collective bargaining rights to field workers because such rights might endanger harvests but this argument is not persuasive. Packinghouse and shed workers who are organized have not disrupted harvest operations, although they are in a position to do so." Id. at 287. Neither the Governor nor any other witness noted, however, that these precise arguments had been presented before regarding these very processing workers.

171 ATter, Labor Retations IN THE HawaItaN SUgar INDUSTRy 58-61 (1957). 
International Longshoremen's and Warehousemen's Union. The IIWU seenied to be a union that would

challenge management at every turn, expropriating managerial authority, slowing down the work, destroying worker-allegiance to employers, raising costs, and constituting a potential destruction of business. ... It was a union that [according to the image] took control over operations, arrogating to itself the discretion to decide which work should be performed and which should not be performed. ${ }^{172}$

In spite of those fears Hawaiian field workers were and still are organized. Observers agree that bargaining in this area "is as mature as anywhere in the United States."173 During the twenty years that these workers have been represented by the ILWU, they have gained "wages and fringe benefits comparable to those enjoyed by workers in nonagricultural industries."174

The dairy industry provides a further illustration of the unfounded nature of agriculture's fears. Even though Allan Grant, President of the California Farnn Bureau Federation, told the committee that he "personally could not continue in business for many days if [his] dairy operations were placed under strike conditions,"1175 dairy operations in many areas are highly organized from top to bottom, including field workers. ${ }^{170}$

The lessons of history, too easily ignored or passed over in silence in most cases, cannot be overlooked here. Even though the reasons for the agricultural worker exclusion may indeed be "covered deep with history's dust," 1177 they are being resurrected again. The spolsesmen for agriculture keep insisting that differences between industry and agriculture make it imperative to continue the exclusion of farm labor from the mainstream

172 Id. at 55, quoting Brooks, MULTIPLE-INdustry UNIONISM IN HawaII 7-8 (1952). 173 Aller, op. cit. supra note 171 , at $10 \%$.

174 Hearings on S. 1866, supra note 144, at 324 (testimony of Harry Bridges, President of the IIWU). Average hourly earnings for sugar workers, including fringes, are over three dollars. "Both industry groups [sugar and pineapple] have comprehensive medical plans, pensions, paid holidays and vacations, sick leave, and severance pay. Hours of work have been reduced to eight per day and forty per week, with overtime thereafter." Id. at 325 .

175 Id. at 418 . Asked if he would negotiate with a union bargaining agent if his workers would freely elect one, Mr. Grant would not say yes or no: "[I]f they wanted to join . . . I would say there's something the inatter with my relationship with my men." He granted, however, that he would talk with the representative-Congressman Harlan Hagen: "About working conditions?" Grant: "I will talk with him." Id. at 420.

${ }^{176}$ Only two isolated instances of unionization among farmworkers in Cahifornia have survived the organizing efforts of the late thirties: the rnilkers' umions of the Los Angeles and San Francisco milksheds. "These two unions have succeeded in maintaining their status even though parallel organization has failed to expand into other dairy areas of California." FULIER, LABOR RELATIONS IN AGRICULTORE 10-11 (1955). The Teamsters have organized the dairy industry extensively in the northwest area also.

177 See testimony of Willard Wirtz, Secretary of Labor, in text accompanying note 160 supra. 
of American life. The method was illustrated in an exchange between Senator Robert Kennedy and the Farm Bureau's Matt Triggs;

Senator Kennedy: "You look back at what the arguments were against having minimum wage origimally, originally 25 cents an hour, later raising it to 50 cents an hour, the exact same arguments."

Mr. Triggs: "I did not try to do that. I thought I pointed out some distinctions between the characteristics of the farm work force and the characteristics of the farmer-worker relationship that were comparatively unique, and not comparable to industry.

"Of course, if the situation is exactly comparable to industry, we do not have any argument left, but I do not think it is exactly comparable to industry."178

Only the lessons of history can show that these differences, granting that there are some, are really irrelevant to the problem. This does not mean, however, that the differences between ordinary industry and agriculture, particularly the vulnerability to strike during harvest, can be ignored. It is not enough to suggest that the flexibilities of collective bargaining, if mutually and seriously pursued, will take care of this problem. Nor is it sufficient to assert that the demands of labor will be always reasonable. The fact is that no one really knows what may happen if farmworkers become substantially organized. Our experience in this area is too negligible. It must be observed, however, that the earlier efforts of agricultural interests to exempt the food processing industry from the provisions of the NLRA were based on identical arguments and fears. Organized labor was going to ruin agriculture througli its control of processing plants and packing sheds. Because of the same vulnerability and the same perishability of the products, the arguments were just as plausible then. But thirty years' experience lias demonstrated that this hypothesis, however sound on paper, was little more than fictitious fabrication. The real issue now is whether Congress is going to be influenced by arguments which lave been exploded in the food processing industry, an industry which agriculturalists claim as their own.

\section{CONCLUSION}

At the end of the summer of 1966 a representation election was held to determine the bargaining representative of agricultural field workers on the Di Giorgio properties near Delano and Borrego Springs, California. ${ }^{179}$ The outcome of this election demonstrates overwhelmingly that

178 Hearings on S. 1866, supra note 144, at 103-04.

170 The election was conducted under the auspices of the American Arbitration Association (AAA). The procedures were set up by Mr. Ronald W. Haughton, who was appointed by the AAA at the request of Governor Brown. The Governor was concerned with the strike situation in the Delano grape fields, and he desired to establish guidelines for the 
farm workers, when given an opportunity to express their choice, will vote strongly in favor of organization and the collective bargaining principle. Of 873 unchallenged votes, only 12, less than one and one-half per cent, were for no union. ${ }^{180}$ Over ninety-eight per cent of the eligible voters declared themselves in favor of a union. The traditional theme of agriculture, that the workers do not want unionism, that they are content with the current situation, has been proved, in this instance at least, to be without the slightest factual basis.

The results of this election have destroyed agriculture's role as spokesman for its workforce. It is time that the workers themselves be allowed to speak for theniselves, through the free election process. Only extension of federal labor legislation, or its equivalent on the state level, will ensure the attainment of this objective.

The need for federal legislation to protect the agricultural worker was recognized over twenty years ago, following the nost thorough investigation of agricultural labor conditions ever conducted in the United States. The La Follette Committee, noting the tremendous disparity of bargaining power between the individual laborer and agricultural associations, recommended:

The waves of emotional, popular sympathy for this neglected portion of our population have not resulted in any miraculous adjustment. Every panacea but the real one, namely, the erection of a democratic, balanced system of employer-employee relationships, has been urged. The hard task of devising, passing, and enforcing legislation to this end must be assumed. That legislation must assure the enjoyment of the same rights, standards of living, and status to labor in Califormia's agricultural industry as is afforded by our laws and customs to other labor. No less measure of public intervention will suffice. ...

The first and fundamental public policy which the Committee recommends is the enactment of such legislation as is necessary to protect the rights of agricultural labor in California to organize and bargain collectively. ${ }^{181}$

holding of representation elections in agriculture. The interested parties-the Di Giorgio Corporation, the Western Conference of Teamsters, the Agricultural Workers Organizing Committee (AWOC), and the National Farm Workers Association (NFWA)-all agreed to Mr. Haughton's procedural directions. The election was held on Aug. 30, 1966. The AWOC and the NFWA were merged by this date and represented one choice on the ballot; the Teamsters were the second, and there was a place for a "non-union" vote. NFWA-AWOC obtained 530 votes from the field worker unit (there was a second unit of non-field workers); the Teamsters received 331 ; there were 12 votes for no umion. See San Francisco Chronicle, p. 1, col. 6, Sept. 3, 1966.

180 Some 332 votes were challenged, of which 253 were eliminated. All parties agreed that the remaining 79 would not cliange the results of the election. Ibid.

181 S. REP. No. 1150, 77th Cong., 2d Sess. 394 (1942). 
As the years have passed the disadvantaged status of agricultural labor, particularly the seasonal farmworker, has not changed. The same forces that prevented legislation from being enacted twenty and thirty years ago are active today. Of the various rationalizations that have been asserted to explain congressional reluctance-agriculture's political power, lack of jurisdiction under the Constitution's commerce clause, administrative difficulties, the unique character of farming as opposed to industry ${ }^{182}$ - only the first and last have had any significant influence on legislators. ${ }^{183}$ The distinguishing characteristics of agriculture definitely do not deserve the attention they have received. The history of organized labor in the food processing industry - an industry which, by agriculture's admission, ${ }^{184}$ is indistinguisliable from farming operations in so far as organized labor's impact is concerned - cannot be passed over. That history more than demonstrates the insufficiency, the irrelevancy, and the poverty of agriculture's position against legislation which would protect their workers in any attempt at self-organization.

The long exclusion of farmworkers from the nation's labor legislation is not entirely a result of agriculture's political power. While it is undeniably a major factor, it must be admitted that the public at large, farmworkers themselves, and particularly the forces of orgamized labor have, until recently, never resisted, nor even protested, the flow of legislative events. Congressmen are not insensitive to the needs of the people. They are capable of resisting the pressures of special interests to achieve necessary legislation; but they need more support than they have received to date if they are to enact legislation to protect farmworkers by equalizmg their bargaining position.

This support is finally growing; organized labor is assuming its neglected responsibilities, and farmworkers are finding a voice of their own. Their appeals will not be unleeded; and they will be aided immeasurably if legislators can be made to see that agriculture's traditional, almost immemorial, arguments against unionization of the farm work force are built on sand. They have provided a shield behind which political power can find sleelter. Destroy the shield - a fabrication of unsound arguments, imaginary fears, and reaction - and the political power will be exposed. It will not bear up against the voice of the people.

182 See text accompanying notes 20-21 supra.

${ }^{183}$ It should be observed that Mr. McDaniel, who suggested the reasons for congressional inaction in this area (see note 106 supra), seems not to have been impressed by them himself when he was urging a broader definition of the term "agricultural laborer" in 1939. See Hearings on S. 1000, S. 1264, S. 1392, S. 1550, S. 1580, and S. 2123 Before the Senate Committee on Education and Labor, 76th Cong., 1st Sess. 3620-45 (1939).

${ }^{184}$ See text accompanying notes $88,98,127$ supra. 